\title{
Petrogenesis of the tholeiitic basalt, calc-alkaline basaltic andesite and high magnesian andesite lava succession of the Oligo-Miocene Anamizu Formation in northeastern Noto Peninsula, central Japan
}

\author{
Juan Carlos López and Akira IshiwATARI \\ Department of Earth Sciences, Faculty of Science, Kanazawa University \\ Kakuma, Kanazawa 920-1192, Japan
}

\begin{abstract}
The Oligo-Miocene Anamizu Formation in the Ushitsu-Matsunami area consists of a lower volcano -sedimentary member and an upper volcanic member. The upper member is essentially composed of three lava series; tholeiite (basalt and basaltic andesite), calc-alkaline (basaltic andesite) and high-magnesian andesite (bronzite andesite), in ascending order. The tholeiitic basalt is further divided into $\mathrm{K}$-poor and $\mathrm{K}$-rich ( $\mathrm{K}$-feldespar bearing) types. The tholeiitic basaltic andesite has higher $\mathrm{FeO}^{*} / \mathrm{MgO}(\sim 3)$ than the others (1-1.5). The calc-alkaline basaltic andesite has higher $\mathrm{Cr}$ and $\mathrm{Ni}$ than tholeitic basaltic andesite. Bronzite andesite contains higher $\mathrm{MgO}, \mathrm{Cr}$ and $\mathrm{Ni}$ than common calc-alkaline andesite of the same $\mathrm{SiO}_{2}$ content $(\sim 60 \mathrm{wt} \%)$, but lower than those of boninite and sanukite. All the rock series are depleted in HFSE ( $\mathrm{Nb}$ and $\mathrm{Ti}$ ) in comparison with $\mathrm{N}-\mathrm{MORB}$ and OIB, suggesting typical subduction-related arc magmas. High $\mathrm{Zr} / \mathrm{Y}$ ratios of the tholeitic basalt resemble those of active continental margin magmas rather than island-arc magmas. The HFSE, Ni and $\mathrm{Cr}$ compositions indicate a progressive depletion or increasing degree of partial melting of the mantle wedge source in the order tholeiite basalt (basaltic andesite) $\rightarrow$ calc-alkaline basaltic andesite $\rightarrow$ bronzite andesite. Spinel in the three series shows different trends: $\mathrm{Cr}^{-}$ poor $(\mathrm{Cr} \# 0.49$ to 0.54$)$ in the tholeiitic basalt, fairly $\mathrm{Cr}$-rich $(\mathrm{Cr} \# 0.61)$ in the calc-alkaline basaltic andesite, and $\mathrm{Cr}$-rich ( $\mathrm{Cr} \# 0.73)$ in the high-magnesian andesite. These trends indicate different mantle restites; lherzolite for the tholeiitic basalt and harzburgite for the calc-alkaline basaltic andesite and highmagnesian andesite, and increasing degree of depletion in the order as above. On the contrary, LILE and LREE exhibit a gradual enrichment of the source in the same order. Corresponding decrease of $\mathrm{TiO}_{2} / \mathrm{K}_{2} \mathrm{O}$ suggests that the enrichment has been due to addition of fluids derived from the descending slab. These data indicate that the $\mathrm{K}$-poor tholeiitic basalt magma has been formed by partial melting of the lherzolitic upper mantle wedge under almost anhydrous conditions; whereas the $\mathrm{K}$-rich tholeiitic basalt magma may have been produced by partial melting of the metasomatized lherzolitic mantle source under slightly hydrous conditions. The calc-alkaline and bronzite andesite magmas have been produced by partial melting of the hydrous, metasomatized, harzburgitic mantle wedge. The stratigraphy of the lava succession in the studied area (tholeiite basalt-basaltic andesite $\rightarrow$ calc-alkaline basaltic andesite $\rightarrow$ bronzite andesite) indicates that depletion and hydration (metasomatism) of the mantle source have progressed simultaneously.
\end{abstract}

\section{Introduction}

The close spatial association of the subduction zone with the arc magmatism suggests an important role of the subducted slab in the genesis of arc magmas. The slab-derived component may be either an aqueous fluid

\footnotetext{
J.C. López, lavile@nihonkai.kanazawa-u.ac.jp Corresponding author

A. Ishiwatari, geoishw@ kenroku.kanazawa-u.ac.jp
}

or a hydrous silicate melt generated in the subducted oceanic crust, subducted sediments, or both (Hickey and Frey, 1982; Tatsumi and Ishizaka, 1982b; Saunders et al., 1987; Defant and Drummond, 1990; Tatsumi, 1991; Stern and Kilian, 1996). On the other hand, both harzburgite and lherzolite are recovered as mantle xenoliths in western Japan (e.g. Arai and Muraoka, 1992; Arai et al., 2000), and both are referred to as the mantle sources of their host magmas (e.g. Shukuno and Arai, 1999). However, temporal changes in the mantle 
source of a single volcanic field have not been documented in such areas dominated by monogenetic volcanoes. In this respect, a detailed geochemical study of the superposing arc lavas of widely different compositions may reveal temporal changes of the source mantle, such as progressive depletion due to magma extraction and progressive enrichment due to reaction with the slabderived melt or fluid. In continental arcs, the magma can also interact with the crust during ascent.

In Noto Peninsula, the Oligo-Miocene Anamizu Formation, a volcanic-sedimentary sequence constituting a part of the Green Tuff, is the most widely distributed unit in the peninsula. Presence of several magmatic series has been reported in this formation of the northwestern area. The series includes tholeiitic basalt, calcalkaline andesite, and high-magnesian andesite (Ishida and Masuda, 1956; Hoshina, 1984; Sato et al., 1989; Shimazu et al., 1993; and Uematsu et al., 1995). The present study reveals for the first time the lava stratigraphy of these different magmatic series of the formation in the Ushitsu-Matsunami area. Gradual and systematic chemical changes through time among the three series of lavas suggest a progressive depletion and enrichment of the same mantle source, contrary to the multi-origin magmatism proposed for the other Green Tuff areas in the Japan arc (Tamura, 1994; Uematsu et al., 1995; Tamura and Nakamura, 1996).

In order to discuss the origin of these series, field relations, petrological, mineralogical and geochemical characteristics of the Anamizu Formation lavas are documented in this paper. The study permitted to consider the progressive changes in the source mantle and its relation to the opening of the Japan Sea.

\section{Geological Setting}

\section{General geology}

The Noto Peninsula is mainly composed of Cenozoic volcanic and sedimentary rocks covering the Paleozoic -Mesozoic Hida gneiss and granite intrusions (Fig. 1) (Ishida, 1959; Tanaka and Nozawa, 1977; Shibata et al., 1981, Sato et al., 1989; Hoshina, 1984; Fujii et al., 1992; Kaseno, 1993; Shimazu et al., 1993; and others). The main part of the Cenozoic sequence is composed, from the lower part to the upper one, of the Oligo-Miocene volcano-sedimentary sequence, the Anamizu and Yanagida formations, deposited in non-marine environment. The Anamizu Formation includes mafic and intermediate lavas, volcanic breccia and sedimentary rocks. $\mathrm{K}-\mathrm{Ar}$ ages of $27.9 \pm 0.9$ to $19.7 \pm 0.5 \mathrm{Ma}$ and 20.5 to $14.8 \mathrm{Ma}$ were obtained for the Anamizu Forma- tion rocks from northern Noto Peninsula (Shibata et al., 1981), and the Hegura-jima and Nanatsu-jima Islands (Sato et al., 1989), respectively. These ages indicate late Oligocene-Early Miocene. The Yanagida Formation (early Middle Miocene; Ishida, 1959; 1970; Shibata et al., 1981) is consisted of acidic pyroclastic rocks, which are mostly distributed on the northeastern part of the peninsula. These volcanic formations are covered by the Miocene-Pliocene sequence, composed of sedimentary and volcanic rocks formed in a marine environment.

The area was disturbed by extensional deformation during the Miocene time, producing horst-graben structure. However, a subsequent compressional deformation also slightly affected the area since the Pliocene. As a consequence, the Oligo-Miocene sequence forms slightly tilted, nearly flat blocks (horsts and grabens), with local folding along the faults.

\section{Geology of the studied area}

The area is located around Ushitsu and Matsunami villages in the northeastern part of Noto Peninsula, central Japan (Fig. 1).

The Ushitsu-Matsunami area is composed of the Oligo-Miocene Anamizu and Yanagida formations, and Quaternary alluvial and marine deposits (Figs. 2 and 3a). The Anamizu Formation is covered by the Yanagida Formation that contains tuffs (rhyolite, dacite and minor andesite), breccias, welded tuff, volcanic sandstone and minor conglomerate. Fossil plants (such as silicified or carbonized trees) are present in the pyroclastic breccia as well as in the conglomerates.

E-W trending horsts and grabens constitute the general structure of the area (see Fig. 2). They form long and narrow tilted blocks, subparallel in direction, bounded by faults. The Oosawa-Nagao block represents the biggest horst in the area. The other minor blocks are Koiji, north Matsunami and Tatekabe. The grabens include the Matsunami-Kurikawashiri, Mawaki-Shimbo, Tsubone, and Shiromarugawa blocks. The Mawaki-Shimbo block is further subdivided into two grabens by a small transversal $(\mathrm{N}-\mathrm{S}$ trending) horst located between Mawaki and Ogi. Fault-related hot springs are present in north Mawaki and south Koiji.

On the other hand, the Ishiyasumiba area (east Wajima), whose bronzite andesite is used for comparison in this study, is composed of the Anamizu Formation. The sequence includes tholeiitic porphyritic basalt lava at the base, bronzite andesite lavas, as well as adakite-like andesite, which are covered by tuffs and breccia (see Uematsu et al., 1995 for geological details). The lavas strike $\mathrm{N} 45^{\circ} \mathrm{E}$ and dip $50^{\circ}-60^{\circ} \mathrm{NW}$. 


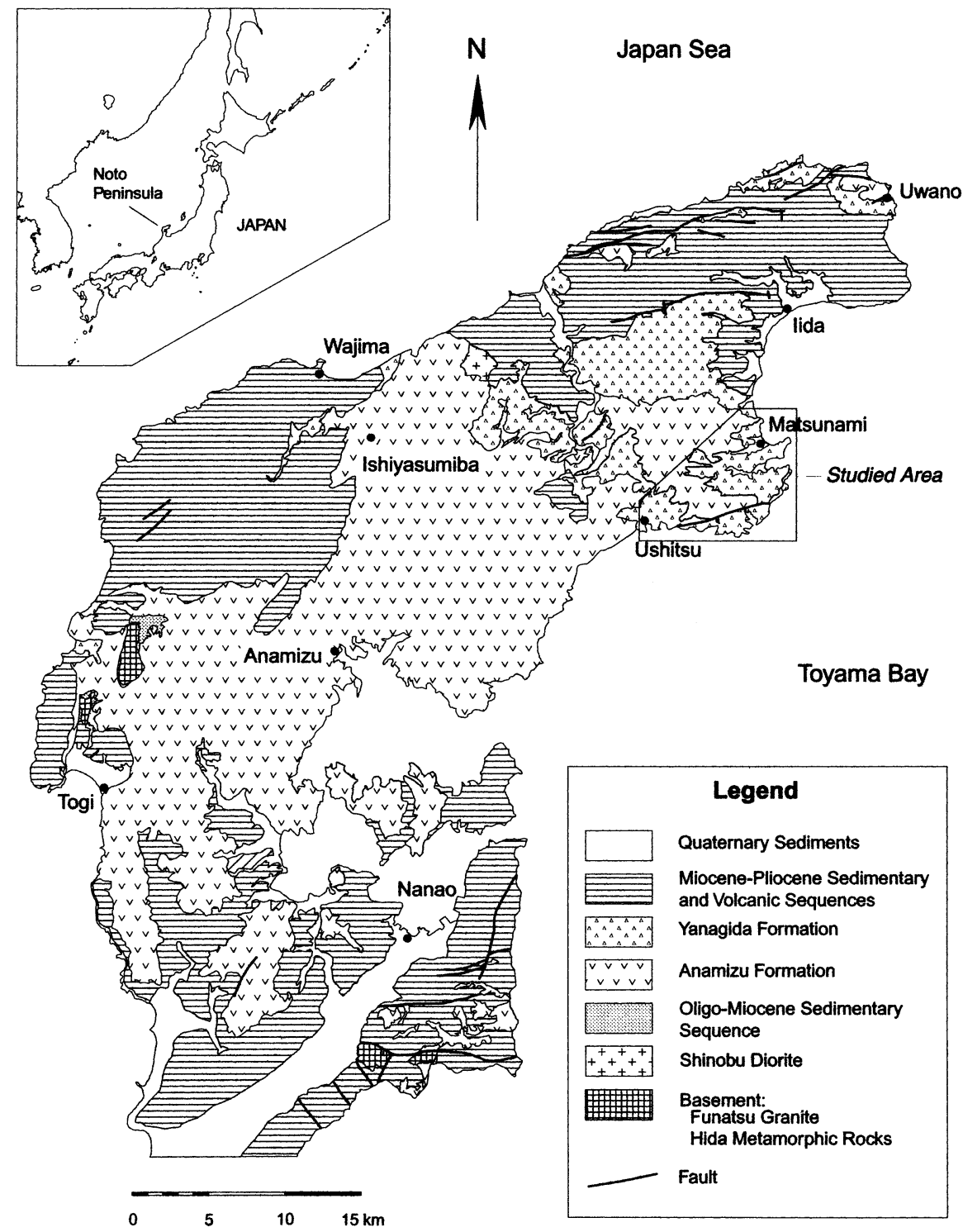

Figure 1. Geological map of Noto Peninsula adapted from Kaseno (1993). Enclosed area represents the studied area, and inset map shows location of Noto Peninsula.

\section{Anamizu Formation}

The Anamizu Formation, widely exposed in Noto Peninsula, shows restricted distribution in the UshitsuMatsunami area as a consequence of the faulting (Fig. 2). The Anamizu Formation has been subdivided into two sequences: the lower volcano-sedimentary member and the upper volcanic member (mainly lavas) (see Fig. $3 a, b)$.

\section{Lower Member}

Good exposures are present in the Oosawa-Nagao block, especially in Oosawa Creek and Fukugami; while minor outcrops are located in Koiji and at north of Matsunami. A thick massive volcanic conglomerate (more than $30 \mathrm{~m}$ ) is present at the base of the sequence in Oosawa Creek, covered by a volcanic breccia. In other places, like Koiji, north of Matsunami, Fukugami and east of Mawaki, only red mudstone and minor finegrained sandstones are exposed. In Fukugami, the red arkosic sandstone contains fragments of basaltic andesite. The volcano-sedimentary member has also been reported in other localities of Noto Peninsula, such as in Nishitani (Hoshina, 1984; Shimazu et al, 1993), Anamizu-Ushitsu and Uwano (Ishida, 1959; 1970).

\section{Upper Member}

The upper member is composed of three different lava series in stratigraphic succession; tholeiitic rocks, calcalkaline rocks and high-magnesian andesite (HMA) in 


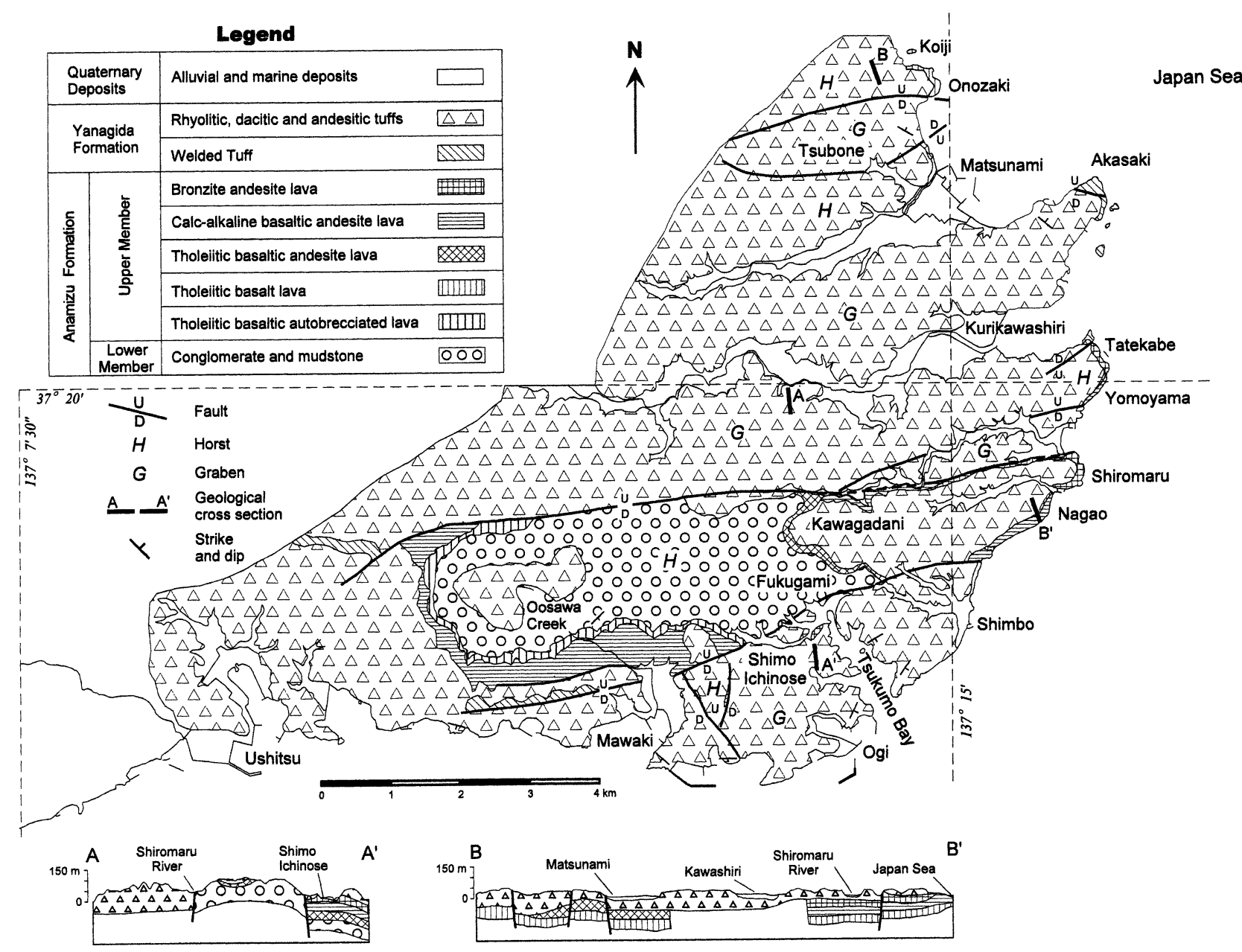

Figure 2. Geological map of the Ushitsu-Matsunami area, northeastern Noto Peninsula.

ascending order. Its total thickness attains more than $70 \mathrm{~m}$. The tholeiitic rocks contain basaltic autobrecciated lava, greenish gray doleritic lavas, and dark gray basaltic andesite lavas, listed from the base to the top. Tholeiitic basalts are exposed at Koiji, south Nagao (containing K-feldespar) and Oosawa Creek, while tholeiitic basaltic andesite occurs at Fukugami and north of Matsunami. Calc-alkaline series includes only dark gray basaltic andesite overlying the tholeiitic rocks, and crops out at Tatekabe, south Nagao, northwest Ogi and north of Mawaki. High magnesian andesite is represented by bronzite andesite lavas, exposed at Tatekabe, Shiromaru-Nagao, and Shimo Ichinose. This andesite overlies the calc-alkaline basaltic andesite, and underlies the Yanagida Formation.

\section{Field relationship of the Anamizu Formation lavas}

Field relationships of the Anamizu Formation lavas exposed at different places throughout the UshitsuMatsunami area are described as follows from north to south (Fig. 3a).

Koiji-Matsunami shoreline outcrops

In Koiji, laminated red and green mudstone forms the base of the sequence, underlying a dark gray doleritic, tholeiitic basaltic lava, which has a clinker containing blocks of more than $20 \mathrm{~cm}$ in size, some of them having vesicular borders. The lava exhibits medium-grained olivine, plagioclase and clinopyroxene that can be macroscopically observed in hand-specimen. Another doleritic dark gray tholeiitic basaltic lava containing similar minerals covers the former. A thin green mudstone layer occurs at the top of this lava, which underlies another doleritic, tholeiitic basalt. The total thickness of these lavas is estimated to be more than $20 \mathrm{~m}$.

In northern Matsunami, the base of the sequence is constituted by arkosic sandstone (more than $1 \mathrm{~m}$ thick), which is overlain by a coarser arkosic sandstone, $60 \mathrm{~cm}$ thick, containing tholeiitic basaltic andesite pebbles and cobbles. Gray tholeiitic basaltic andesite lava having a thick basal clinker overlies the sandstone. This lava is 


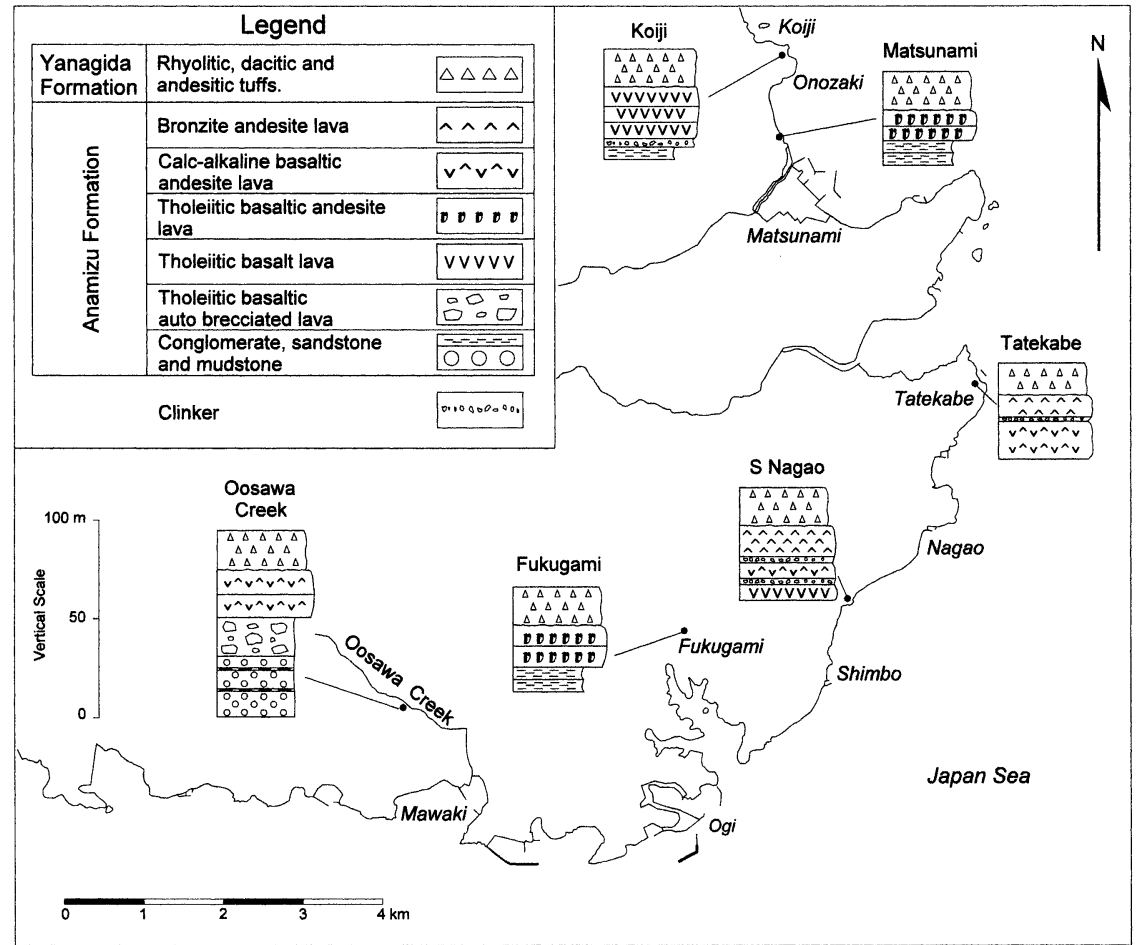

(a)

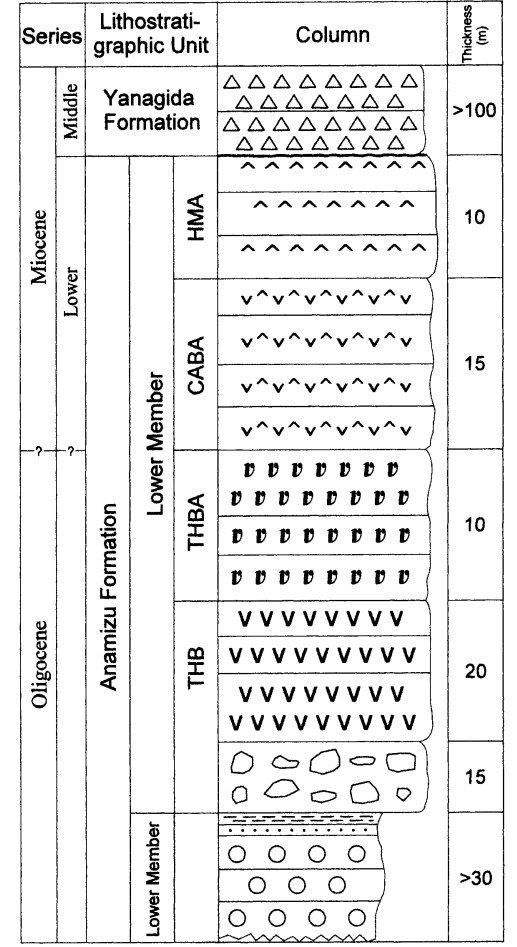

(b)

Figure 3. Lithostratigraphic succession of the Anamizu Formation in Ushitsu-Matsunami area. a) Succession and distribution of the Anamizu sequence cropping out in different places of this area. b) Reconstructed general succession of the Anamizu Formation in the area. THB, tholeiitic basalt; THBA, tholeiitic basaltic andesite; CABA, calcalkaline basaltic andesite; HMA, high-magnesian andesite (bronzite andesite).

plagioclase- and olivine-phyric, and has a thickness of $2.5 \mathrm{~m}$. Another porphyritic tholeiitic basaltic andesite containing a thick clinker (autobreccia), very similar to the previous lava, occurs at the top of the Anamizu Formation. These tholeiitic lavas are overlain by the acidic tuffs of the Yanagida Formation.

Tatekabe-Nagao shoreline outcrops

The base of the sequence is exposed at southwestern Nagao as a small outcrop, and is represented by dark gray tholeiitic basaltic lava (dolerite) containing medium-grained olivine, plagioclase and clinopyroxene. As the lava has been strongly altered, it shows a greenish (or reddish) color. Laterally, on both sides, aphyric dark gray calc-alkaline basaltic andesite lava is present, and may overlie the former lava. This rock containing microphenocrysts of olivine, plagioclase and clinopyroxene, is partially vesicular, and presents a clinker $(50 \mathrm{~cm}$ thick) at the base. The exposure of this clinker over a relatively wide area along the shoreline of Nagao suggests a sub-horizontal attitude of the lavas.

At Shiromaru and Tatekabe on the north, a dark gray and characteristically aphyric bronzite andesite lava is exposed. This lava has a thin clinker (more than 20 $\mathrm{cm})$. It is noteworthy that the lava has strong platy joints with strike of $\mathrm{N} 80^{\circ} \mathrm{W}$ and $30^{\circ} \mathrm{N}$ dip. The joint planes are sub-parallel with less than $5 \mathrm{~cm}$ interval. In both places, calc-alkaline basaltic andesite lavas are exposed on the south of the bronzite andesite.

These geological relationships indicate that the bronzite andesite lava covers the calc-alkaline basaltic andesite lava. Although their direct contacts are hidden, it is supposed to cover the tholeiitic basalt lava. The Yanagida tuffs overlie all the Anamizu lavas. However, at Tatekabe, the bronzite andesite lava is in fault contact with the Yanagida Formation ignimbrite.

Fukugami roadside outcrops

The base of the sequence contains stratified red mudstone and sandstone, having small blocks (less than 10 $\mathrm{cm}$ ) of basaltic andesite at the top. Overlying these sediments is a dark gray porphyritic, tholeiitic basaltic andesite ( $4 \mathrm{~m}$ thick), containing small phenocrysts of plagioclase and altered olivine. There is a thin basal clinker $(30 \mathrm{~cm}$ thick) having basaltic andesite blocks enclosed into a sandy matrix. Reddish porphyritic tholeiitic basaltic andesite lava with a thickness of $4 \mathrm{~m}$ occurs at the top of the sequence. It contains pheno- 
crysts of plagioclase $(\sim 4 \mathrm{~mm})$, olivine $(\sim 2 \mathrm{~mm})$, and less amount of clinopyroxene. The Yanagida tuffs overlie this lava.

Oosawa Creek roadside and river floor outcrops The largest exposure of the Anamizu Formation is found along this stream. The base of the sequence is represented by a volcanic conglomerate, more than $30 \mathrm{~m}$ thick, containing boulders and cobbles (less than $70 \mathrm{~cm}$ of diameter) of basaltic andesite enclosed in a sandy matrix, with some thin red mudstone. A volcanic breccia (autobreccia) of tholeiitic basalt composition, aphyric and dark gray colored, overlies the conglomerate. The thickness of the breccia is estimated to be more than $15 \mathrm{~m}$. At the top of the sequence, a dark gray aphyric calc-alkaline basaltic andesite with small phenocrysts of plagioclase and olivine is present. This lava may have a thickness of more than $15 \mathrm{~m}$. All this sequence is overlain by the Yanagida Formation.

\section{Petrography}

\section{Tholeiitic basalt and basaltic andesite (THB and THBA)}

Mineral assemblages of tholeiitic rocks are shown in Table 1. Tholeiitic basalt includes two different types: common tholeiitic rock and $\mathrm{K}$-feldspar bearing one, both of them containing a major phenocryst assemblage of plagioclase + olivine + clinopyroxene.

Basalts of the first type are exposed in the northern part, namely Koiji and Onozaki areas. They are doleritic rocks characterized by ophitic and subophitic texture. Plagioclase is the most abundant phase, appearing as euhedral and subhedral crystals (up to $1.5 \mathrm{~mm}$ ), usually twinned and zoned. Olivine occurs as visible crystals (up to $2.5 \mathrm{~mm}$ ), forming in some case glomerocrystal aggregates. Fresh olivine occurs only in Koiji Island, whereas it appears as pseudomorphs, alterated to chlorite, and is rimmed by iddingsite at Onozaki. All of them contain spinel as inclusions. Clinopyroxene (augite) also occurs as subhedral to anhedral crystals (up to $2.5 \mathrm{~mm}$ ), filling the interstices of the olivine-plagioclase frame. Other minor phases are titanomagnetite, cristobalite and glass (partially altered to chlorite). Xenocrystic plagioclase has been found in Koiji as a subordinate component.

The second type, Nagao basalt, is also doleritic and shows similar mineral assemblage as the former, i.e. plagioclase-augite-olivine, but additionally includes potassium feldspar and pigeonite. Plagioclase occurs as subhedral to euhedral, lath-like crystals (up to $1.2 \mathrm{~mm}$ ) rimmed by potassium feldspar. Olivine (up to $1.8 \mathrm{~mm}$ ) is completely altered to chlorite, and having rims of iddingsite in some cases. There are spinel inclusions in some olivine. Clinopyroxene (augite) occurs as big anhedral to subhedral crystals (up to $2 \mathrm{~mm}$ ). Potassium feldspar also occurs as microlites filling interstices in close relation to glass-rich groundmass. Moreover, small crystals of pigeonite (up to $0.2 \mathrm{~mm}$ ) and titanomagnetite are also present as groundmass phases.

Basaltic autobreccia with aphyric and trachytic texture containing microphenocrysts of olivine and plagioclase is exposed in Oosawa Creek.

The basaltic andesite is porphyritic, intersertal and partially trachytic, containing phenocrysts of plagioclase, spinel-bearing olivine and clinopyroxene. Plagioclase appears as large subhedral phenocrysts (up to $2 \mathrm{~mm}$ ), forming sometimes glomerocrysts. Plagioclase is twinned and zoned, and sometimes is corroded or altered to sericite. Olivine occurs as subhedral to anhedral phenocrysts, up to $2 \mathrm{~mm}$ in size. Olivine is completely altered (pseudomorphed) to chlorite and sometimes contains iddingsite rims. Augite is the minor phase, anhedral to subhedral, and up to $0.8 \mathrm{~mm}$ in size. Spinel occurs as inclusions in olivine pseudomorphs (in Fukugami, spinel is present only in the upper lava).

\section{Calc-alkaline basaltic andesite (CABA)}

Mineral assemblages of calc-alkaline basaltic andesite are presented in Table 1. The rock has a phenocryst assemblage of plagioclase + olivine (spinel bearing) + hypersthene \pm augite, and shows intersertal texture. Plagioclase is the major phase occurring as subhedral phenocrysts (up to $1.1 \mathrm{~mm}$ ), which, in some cases, are altered to sericite. Olivine is pseudomorph in all cases (altered to chlorite), up $1.0 \mathrm{~mm}$ in size. Hypersthene appears as prismatic subhedral phenocrysts (up to 0.8 $\mathrm{mm})$. Augite phenocryst is rare, appearing as small anhedral to subhedral microphenocrysts $(0.2 \mathrm{~mm})$, and, in some cases, as rims in hypersthene. Glass is present in the groundmass.

\section{High-magnesian bronzite andesite (HMA)}

Bronzite andesite from Ushitsu-Matsunami area is aphyric and hyaloophitic with a dark gray color. The rock has a characteristic phenocryst assemblage of bronzite + plagioclase \pm augite in a glass-rich groundmass (Table 1). Bronzite is ubiquitous, and occurs as long prismatic phenocrysts (up to $1.6 \mathrm{~mm}$ ), euhedral to subhedral, sometimes forming glomerocrysts. Some bronzite crystals have augite rims. Plagioclase appears as subhe- 


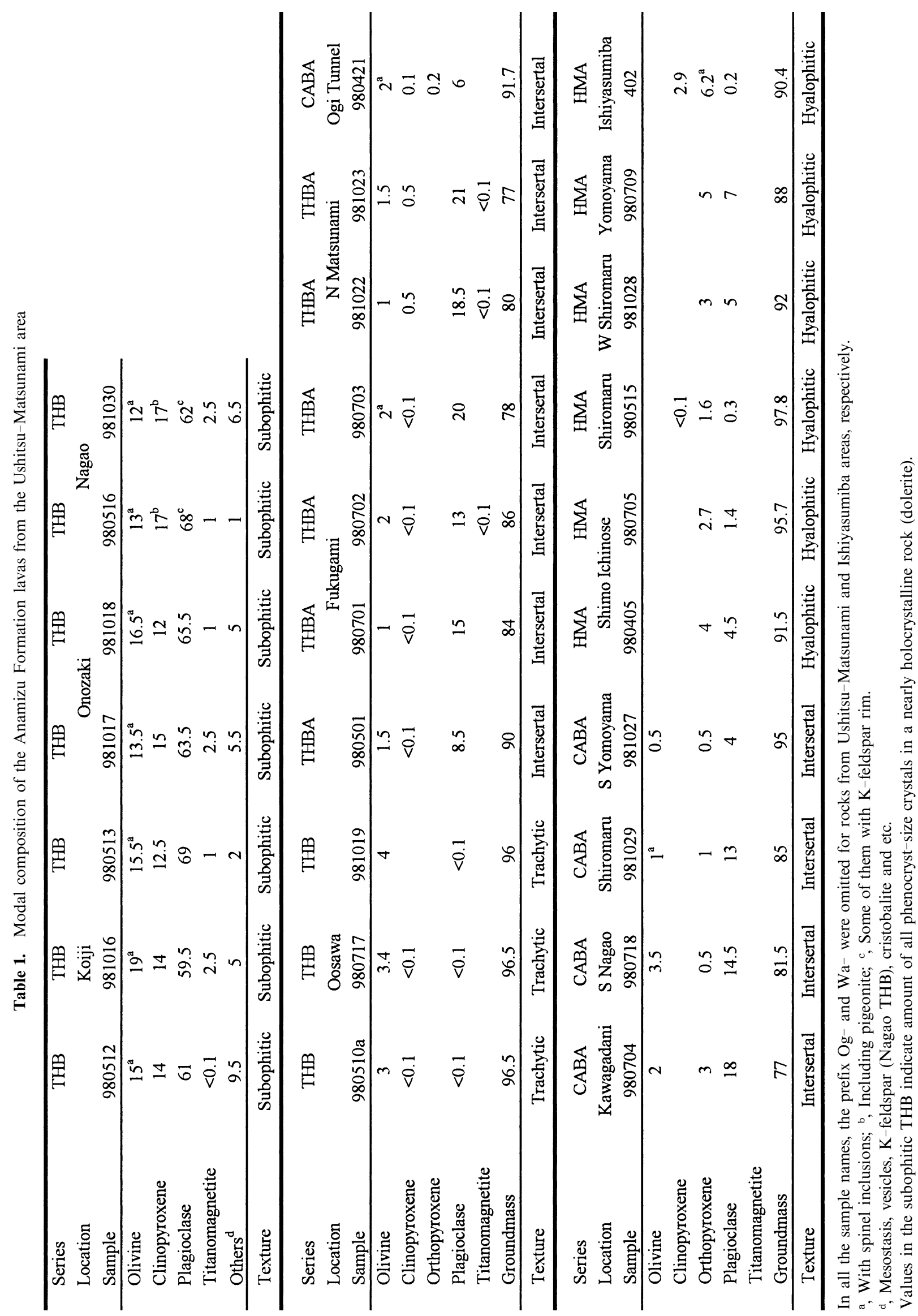


dral crystals, sometimes twinned or zoned, and up to 0.6 $\mathrm{mm}$ in size. In general, plagioclase is clear and devoid of glass inclusions or dusty zones. Augite is present as small subhedral to anhedral microphenocrysts (up to $0.25 \mathrm{~mm}$ ). Olivine has been found at Shiromaru, occurring as pseudomorphs (altered to chlorite) of subhedral microphenocrysts $(0.2 \mathrm{~mm})$. The common occurrence of phenocrystic plagioclase in this bronzite andesite differs from boninite and sanukite, which lack phenocrystic plagioclase.

On the other hand, bronzite andesite from Ishiyasumiba has a phenocrystic assemblage of bronzite + augite \pm plagioclase (Table 1). Bronzite is the dominant phenocrystic phase, occurring as long subhedral phenocrysts (up to $1.6 \mathrm{~mm}$ ). Augite occurs as anhedral to subhedral phenocrysts up to $0.7 \mathrm{~mm}$ size. Plagioclase is a minor phase that is present as subhedral phenocrysts having $0.7 \mathrm{~mm}$ size. In addition, there are xenocrysts of plagioclase (average $1.5 \mathrm{~mm}$ size) and augite $(1.5 \mathrm{~mm})$, both of them anhedral and altered.

\section{Geochemistry}

\section{Analytical procedure}

Major and trace element concentrations were determinated by X-ray fluorescence spectrometry, using a Rigaku $3270 \mathrm{X}$-ray spectrometer at Faculty of Science, Kanazawa University. Glass disks were prepared for major element analysis by fusing the sampled rock powder $(0.5$ g) with lithium tetraborate $\left(\mathrm{Li}_{2} \mathrm{~B}_{4} \mathrm{O}_{7}, 5 \mathrm{~g}\right)$ and lithium bromide (trace) in a platinum crucible, following the method of Nakada et al. (1985). Pressed powder pellets for trace element analysis were prepared using $5 \mathrm{~g}$ of rock powder dosed with polyvinyl alcohol solution, and pressed into standard $30 \mathrm{~mm}$ diameter pellets, following the method of Tamura et al. (1989). Rare earth elements ( $\mathrm{La}, \mathrm{Ce}, \mathrm{Sm}, \mathrm{Eu}, \mathrm{Yb}$ and $\mathrm{Lu}$ ) were measured using the rock powder samples $(0.1 \mathrm{~g}$ each), which were irradiated with thermal neutron in the Kyoto University Reactor for 1 hour, and were analyzed by $\gamma^{-r a y}$ spectrometer at the radioisotope laboratory for scientific and technological studies at Faculty of Science, Kanazawa University. Chemical compositions of minerals were determined by Scanning Electron Microscope (SEM) Akashi Alpha-30A with an energy-dispersive spectrometer Philips EDAX-9100 at Faculty of Science, Kanazawa University.

\section{Whole-rock chemical composition}

Major elements

Major and trace element contents of all series are shown in Table 2 and Figures 4 and 5. Three different volcanic series have been distinguished in the $\mathrm{FeO}^{*} / \mathrm{MgO}^{-}$ $\mathrm{SiO}_{2}$ diagram (Fig. 4a): tholeiitic, calc-akaline and high magnesian andesite (Miyashiro, 1974; Sato, 1989). Some tholeiitic basalts are plotted in the calc-alkaline field. The tholeiitic rocks show typical "island arc tholeiite" trend, but are slightly higher in $\mathrm{TiO}_{2}$ as a whole (Fig. 4b). These three series are also distinguished in the $\mathrm{SiO}_{2}-\mathrm{MgO}$ diagram (Fig. 5a). On the other hand, all the rocks are subalkaline in the silicaalkali diagram (Fig. 5c; after Miyashiro, 1978), and belong to medium- $\mathrm{K}$ series in the $\mathrm{SiO}_{2}-\mathrm{K}_{2} \mathrm{O}$ diagram (Fig. 5d; after Gill, 1981).

Tholeiitic rocks have $\mathrm{SiO}_{2}$ ranges of 51-56 wt.\%, and $\mathrm{FeO}^{*} / \mathrm{MgO}$ ratios of 1.2 and 3.1. The Nagao basalt is higher in $\mathrm{MgO}$ (5.85 to 6.53 wt.\%) and $\mathrm{K}_{2} \mathrm{O}$ (av. 1.2 wt.\%), but lower in $\mathrm{CaO}$ (7.87 to 8.00 wt.\%) than the other tholeiitic basalts. The Nagao basalt has the lowest $\mathrm{FeO}^{*} / \mathrm{MgO}$ (av. 1.18). Tholeiitic basaltic andesite has distinctly higher $\mathrm{FeO}^{*} / \mathrm{MgO}$ (av. 2.6) than calc-alkaline basaltic andesite (av. 1.3).

Calc-alkaline basaltic andesite contains 54 to 57 $\mathrm{SiO}_{2}$ wt.\%, and higher $\mathrm{MgO}$ (4.11 to 5.50\%) and $\mathrm{K}_{2} \mathrm{O}$ (0.94 to 1.81\%) contents than those in tholeiitic basaltic andesite, but similar to other calc-alkaline basaltic andesite reported from Noto Peninsula, such as those of Yanagida (Hoshina, 1984) and Wajima (Uematsu et al, 1995) areas.

Bronzite andesite contains a narrow range of silica, 59 to $61 \mathrm{wt. \%}$, and lower $\mathrm{FeO} / \mathrm{MgO}$ values (1.27). Bronzite andesite has higher $\mathrm{MgO}$ contents (3.48 to $4.42 \%$ for this area and $4.53 \%$ for Ishiyasumiba) than tholeiitic basaltic andesite (Fig. 5), but lower FeO*, $\mathrm{CaO}, \mathrm{Al}_{2} \mathrm{O}_{3}$ and $\mathrm{TiO}_{2}$ than tholeiitic and calc-alkaline basaltic andesites. In general, these values are similar to those of other high-magnesian andesites reported from different localities of Noto Peninsula (Hoshina, 1984; Sato et al., 1989), except for Wajima (Uematsu et al., 1995) and Ishiyasumiba, which have higher $\mathrm{MgO}$ and $\mathrm{CaO}$ contents. The $\mathrm{MgO}$ content of bronzite andesite is higher than common andesites (Gill, 1981; Foden, 1983; Takahashi and Shuto, 1999) and icelandites (Wood, 1978); but it is lower than sanukites (Tatsumi and Ishizaka, 1982a; 1982b) and boninites (Hickey and Frey, 1982; Murton et al., 1992). According to the boninite classification (Crawford et al., 1989), the bronzite andesite of Noto Peninsula may be related to low-Ca boninite, type 2 (high-Si and low $\mathrm{CaO} / \mathrm{Al}_{2} \mathrm{O}_{3}$ ). 


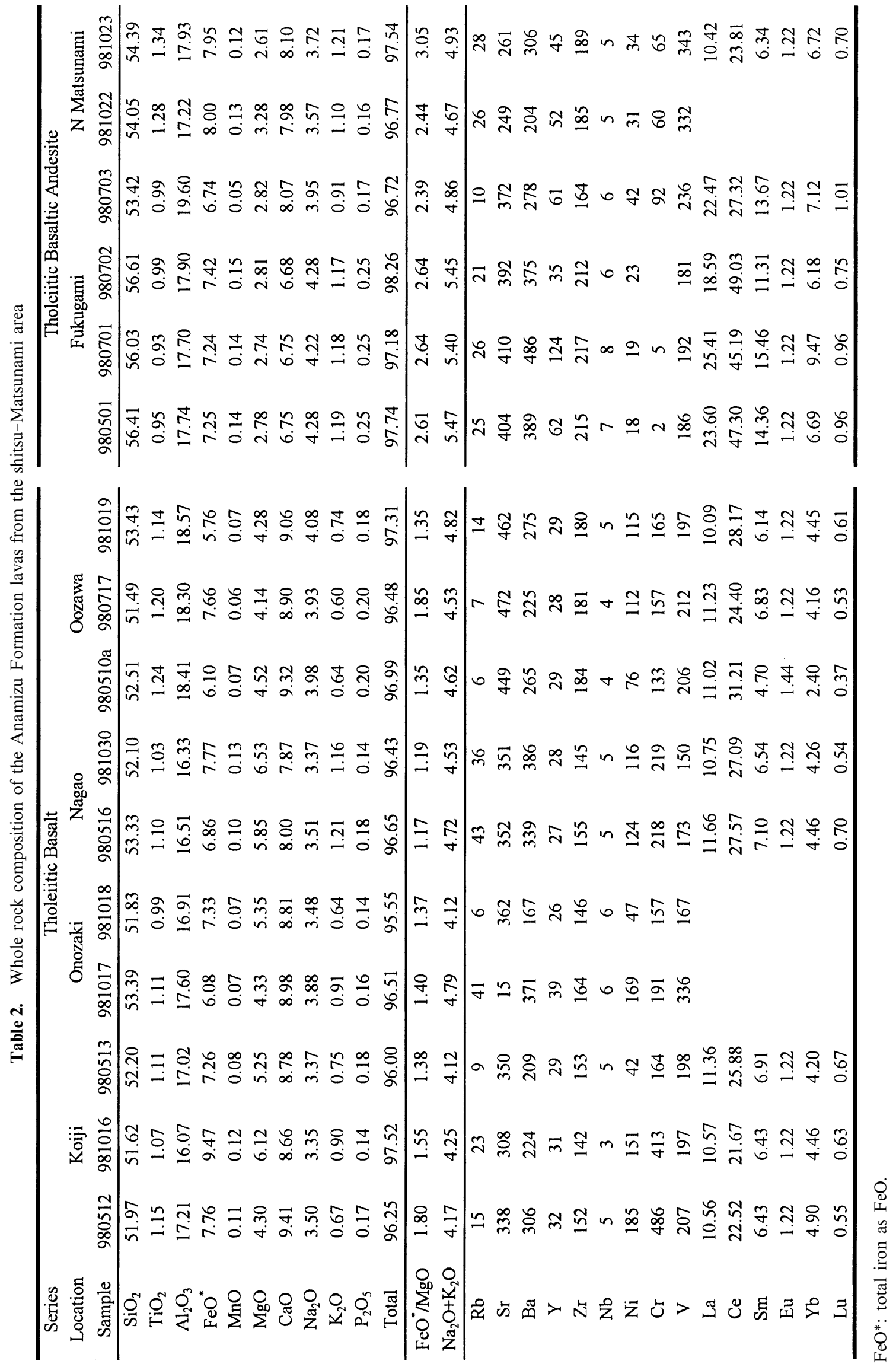


(a)

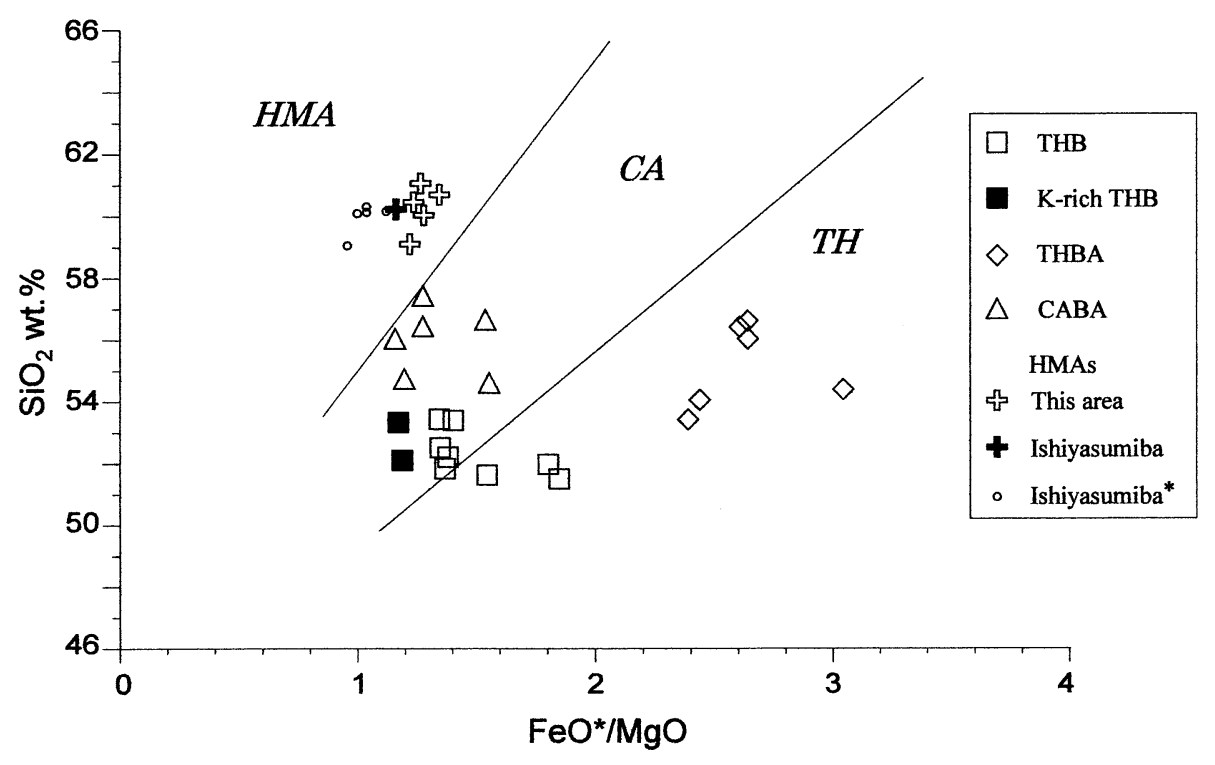

(b)

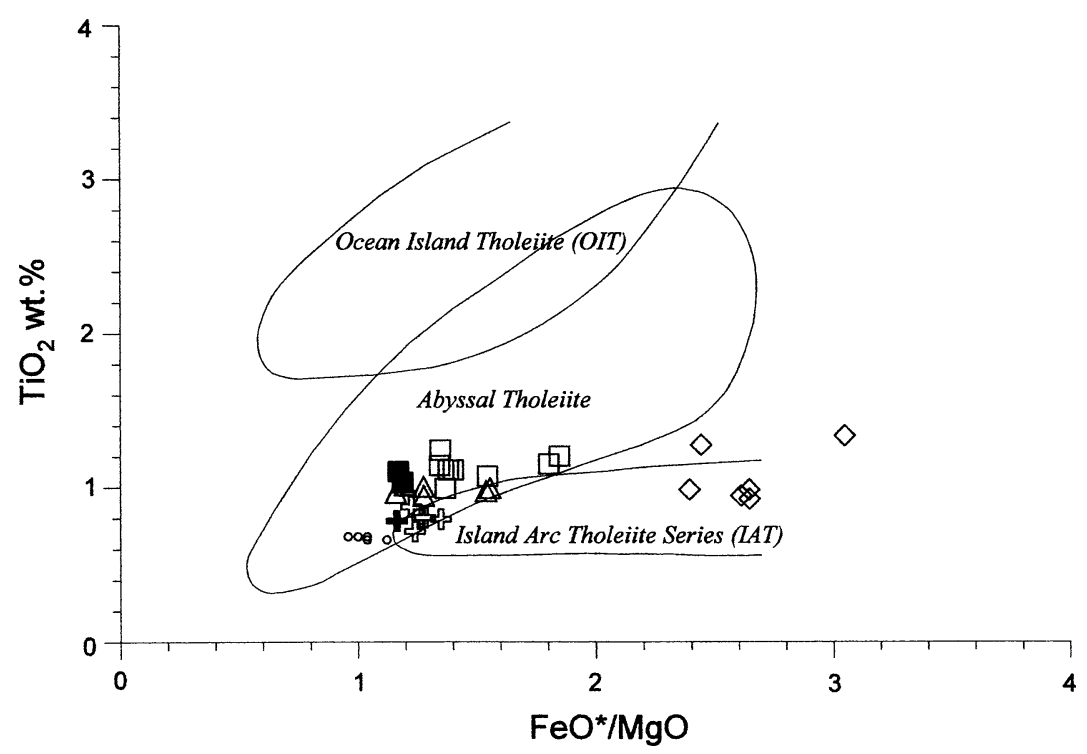

Trace Elements

Trace element contents are listed in Table 2 and plotted in Figure 6.

Tholeiitic $\mathrm{K}$-rich basalt has higher content of large ion lithophile elements like $\mathrm{Rb}$ ( 36 to $43 \mathrm{ppm}$ ) and $\mathrm{Ba}$ ( 340 to $390 \mathrm{ppm}$ ) than the common basalt type ( $\mathrm{Rb} 6-23$ ppm and Ba 170-330 ppm) (Figs. 6a, c and 7).

Calc-alkaline basaltic andesite has higher Ni (41$72 \mathrm{ppm}$ ) and $\mathrm{Cr}(66-224 \mathrm{ppm})$ concentrations than in tholeiitic basaltic andesite (Ni 18-42 ppm and $\mathrm{Cr} 2-92$ ppm) (Fig. 6g, h). Bronzite andesite has higher concen- trations of $\mathrm{Ni}$ (this area: 19-52 ppm; Ishiyasumiba: 101 ppm) and $\mathrm{Cr}$ (this area: 41-86 ppm; Ishiyasumiba: 149 ppm) than common tholeiitic and calc-alkaline andesites of the same $\mathrm{SiO}_{2}$ content occurring along the Japan Sea-side of Japan (Ebihara et al., 1984; Miyake, 1994; Takahashi and Shuto, 1999). In general, all three series rocks are depleted in high field strength elements (HFSE), such as $\mathrm{Nb}$ and $\mathrm{Ti}$, in comparison with the other incompatible elements, as seen in the N-MORBnormalized diagram (Fig. 7). Tholeiitic basaltic andesite shows higher concentrations of $\operatorname{HFSE}$ (Y, Zr and 

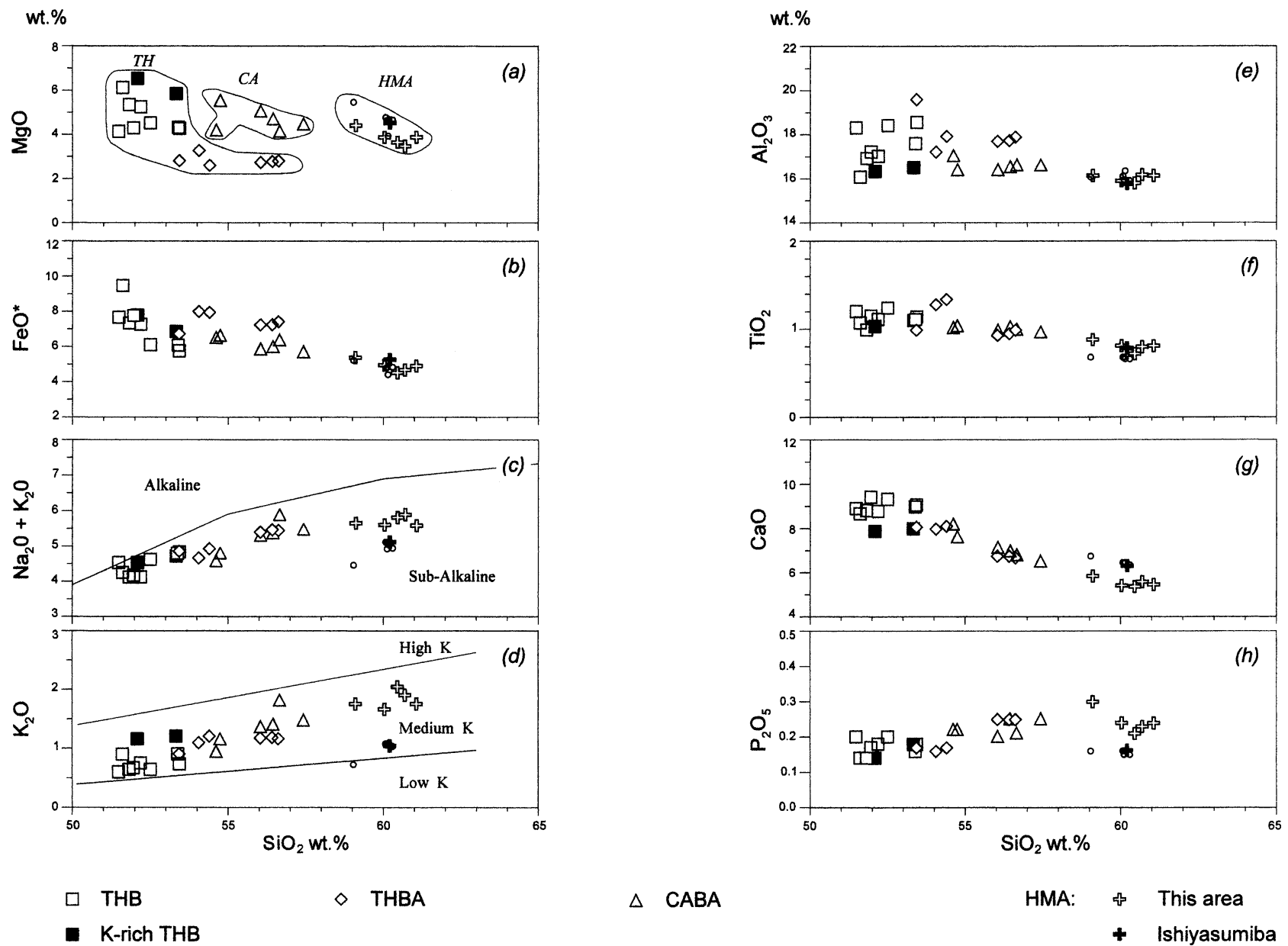

Figure 5. Major element variation diagrams of the Anamizu Formation volcanic rocks. Three clearly different trends are shown on the $\mathrm{MgO}-\mathrm{SiO}_{2}$ diagram: $\mathrm{TH}$, tholeiite; $\mathrm{CA}$, calc-alkaline and $\mathrm{HMA}$, high-magnesian andesite (bronzite andesite). Small circles represent HMA from Wajima (Uematsu et al., 1995).

partially $\mathrm{Nb}$ ) but lower LILE ( $\mathrm{Rb}$ and $\mathrm{Sr}$ ) contents than calc-alkaline basaltic andesite. In addition to this feature, bronzite andesite has lower $\mathrm{Sr}$ contents (this area: $<375 \mathrm{ppm}$; Ishiyasumiba: $563 \mathrm{ppm})$ and $\mathrm{Sr} / \mathrm{Y}$ ratio (this area: $<19$; Ishiyasumiba: 31 ) than those of adakite-like andesite (Sr: $1000 \mathrm{ppm}$ and $\mathrm{Sr} / \mathrm{Y}$ : 70) reported from east Wajima (Uematsu et al., 1995).

All three rocks series show distinctive chondritenormalized rare earth element (REE) patterns characterized by gradual LREE enrichment and HREE depletion, in the order of tholeiite $\rightarrow$ calc-alkaline $\rightarrow$ high -magnesian andesite (Fig. 8). Tholeiitic rocks exhibit REE patterns with a gentle slope, $(\mathrm{La} / \mathrm{Yb})_{\mathrm{n}}$ of 3.6 for basalts and 4.5 for basaltic andesites, which are relatively enriched in HREE. It is remarked that the tholeiitic basaltic andesite is more enriched in LREE than calc -alkaline basaltic andesite, corresponding to its evolved nature, as shown before by high $\mathrm{FeO}^{*} / \mathrm{MgO}$. The calc -alkaline basaltic andesite shows moderate slope of the patterns, $(\mathrm{La} / \mathrm{Yb})_{\mathrm{n}}$ of 7.2 , which is higher than in tholeiitic basaltic andesite but lower than in bronzite andesite. HREE contents of calc-alkaline basaltic andesite are lower than tholeiitic rocks, but somewhat similar to those of bronzite andesite. Bronzite andesite from Uchiura-Matsunami area is the most enriched in LREE, showing higher slope pattern of $(\mathrm{La} / \mathrm{Yb})_{\mathrm{n}}=11.3$. Nevertheless, Ishiyasumiba bronzite andesite, on the contrary, shows both less enriched LREE- and less depleted HREE-patterns, having a gentle slope $(\mathrm{La} / \mathrm{Yb})_{\mathrm{n}}$ of 4.6 .

\section{Mineral composition}

Plagioclase

Representative plagioclase compositions are presented in Table 3 and Figure 9 ( $a$ and b). Plagioclase composition in tholeiitic rocks is characterized to be higher in $\mathrm{CaO}$ but lower in $\mathrm{Na}_{2} \mathrm{O}$ and $\mathrm{K}_{2} \mathrm{O}$ than in calc-alkaline basaltic andesite and bronzite andesite. Compositions of plagioclase cores in basalts are $\mathrm{An}_{57-65}$ in Nagao and 

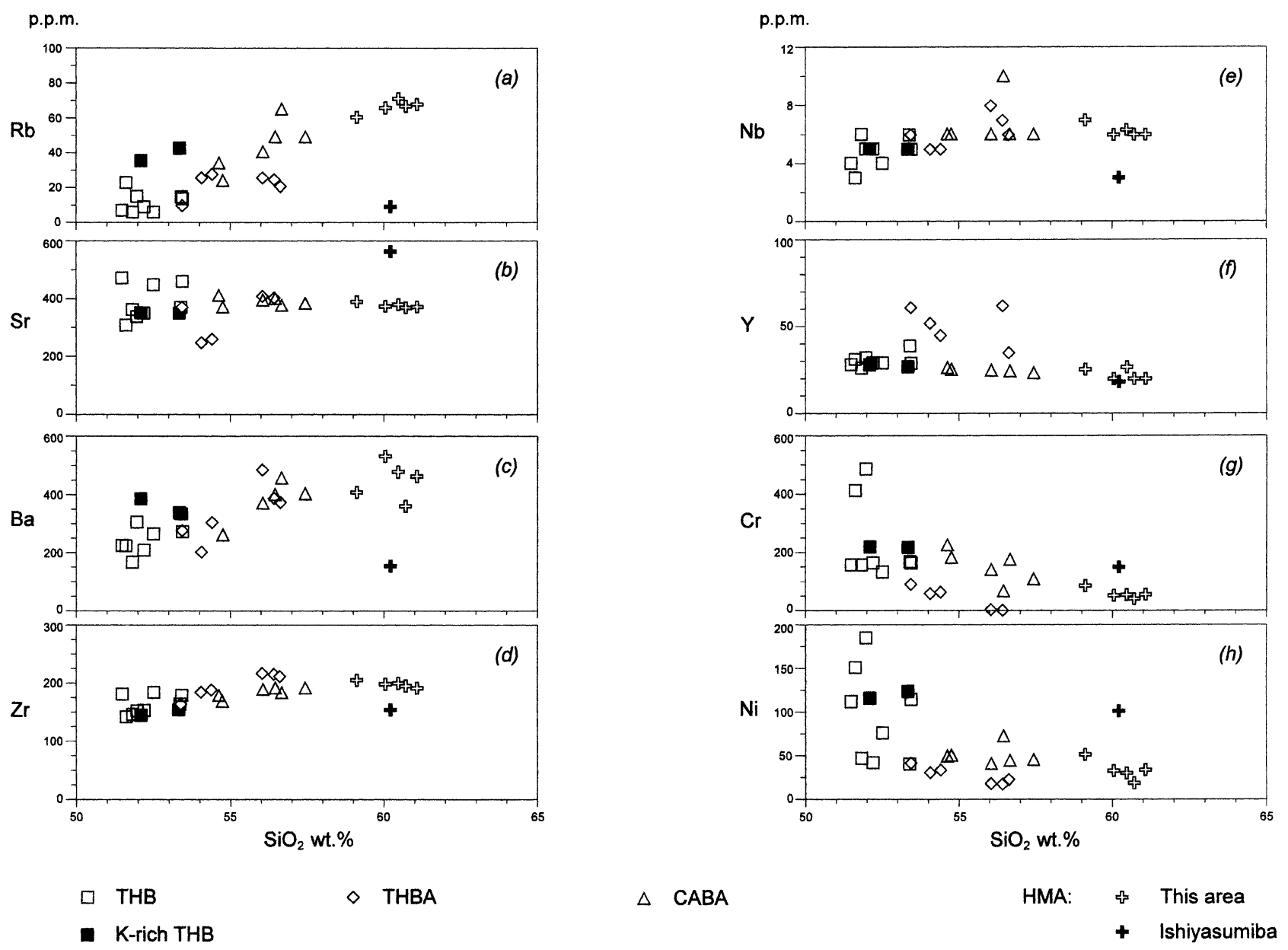

Figure 6. Trace element variation diagrams of the Anamizu Formation volcanic rocks.

$\mathrm{An}_{50-79}$ in Koiji; while groundmass plagioclase has a range of $\mathrm{An}_{50-66}$. In these basalts, plagioclase has normal zoning, i.e., calcic core to sodic rim. On the contrary, plagioclase in basaltic andesite has very wide range of An contents: in Fukugami $\mathrm{An}_{40-91}$ in the lower lava and $\mathrm{An}_{38-86}$ in the upper lava, while in Matsunami area is $\mathrm{An}_{47-89}$. In general, plagioclase zoning is commonly normal type, calcic core to sodic rim, but some plagioclases from the Fukugami lower lava show reversal zoning.

Plagioclase in calc-alkaline rocks is lower in $\mathrm{CaO}$, but higher in $\mathrm{Na}_{2} \mathrm{O}$ and $\mathrm{K}_{2} \mathrm{O}$ than in tholeiitic basaltic andesite. Plagioclase has compositions of $\mathrm{An}_{44-71}$ for the core and $\mathrm{An}_{41-69}$ for the rim. The zoning is generally normal type but in Nagao lava some plagioclases have reverse zoning, i.e., sodic core and calcic rim.

Bronzite andesites contain plagioclase slightly lower in $\mathrm{CaO}$ contents $\left(\mathrm{An}_{46-66}\right.$, with normal type zoning) than calc-alkaline basaltic andesite.
Potassium feldspar

Representative potassium feldspar compositions are presented in Table 3 and Figure 9a. The Nagao tholeiitic basalt contains $\mathrm{K}$-rich feldspar that varies from anorthoclase to sanidine, i.e., $\mathrm{Or}_{4-54}$, with an average of $\mathrm{Or}_{23}$.

\section{Pyroxenes}

Representative pyroxene analyses are presented in Table 4 and plotted in Figure 10a. In tholeiitic rocks, clinopyroxene is characterized to be higher in $\mathrm{CaO}$ (wollastonite composition) compared with the other two series, with the exception of pigeonite found in Nagao lava. In basalt, clinopyroxene has a $\mathrm{Mg} \#\left[100^{*} \mathrm{Mg} /\right.$ $(\mathrm{Mg}+\mathrm{Fe})]$ 65-83, and average composition of $\mathrm{En}_{47} \mathrm{Fs}_{13} \mathrm{Wo}_{40}$. Pigeonite has $\mathrm{Mg} \#$ of 70-72 and composition of $\mathrm{En}_{65} \mathrm{Fs}_{26} \mathrm{Wo}_{9}$. In basaltic andesites, clinopyroxene has generally $\mathrm{Mg} \# 66-77$ and composition of $\mathrm{Wo}_{39}$.

Clinopyroxene in calc-alkaline rocks has also augite composition, but lower in $\mathrm{CaO}$ than tholeiitic 

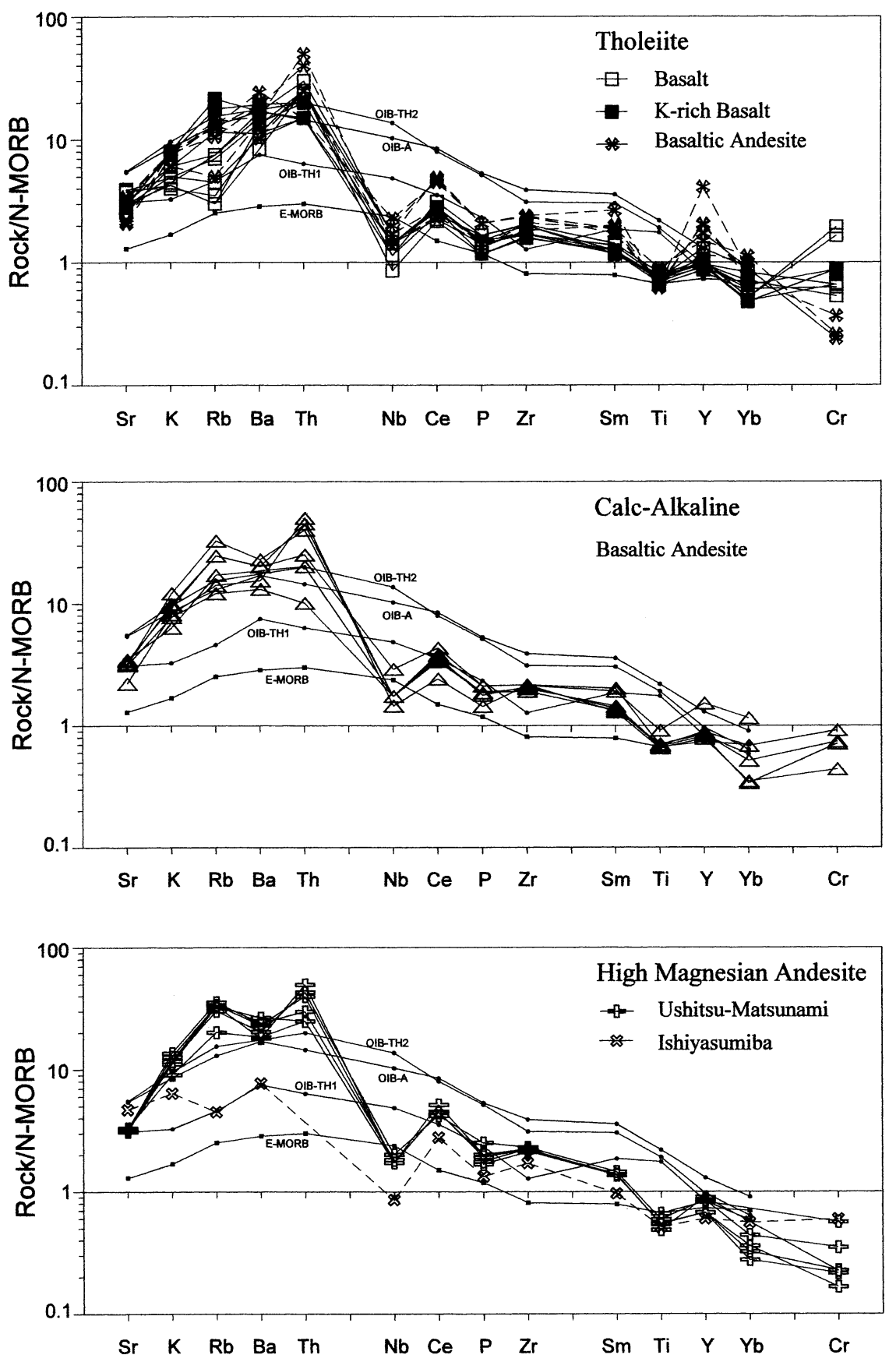

Figure 7. $\mathrm{N}-\mathrm{MORB}$-normalized trace element patterns of the Anamizu Formation volcanic rocks from Ushitsu-Matsunami area (after Pearce, 1983). E-MORB and OIB-TH2 are from Sun and McDonough (1989); OIB-TH1 and OIB-A are from Basaltic Volcanism Study Project (1981).

basaltic andesite (Fig. 10a). The clinopyroxene has $\mathrm{Mg} \#$ 73-80 and average composition of $\mathrm{Wo}_{35}$, while the accompanying orthopyroxene has Mg \# 71-80 (Fig. 10b) and average composition of $\mathrm{Wo}_{4}$ (hypersthene).

Bronzite andesite has orthopyroxene with $\mathrm{Mg} \# 80$ 86, and average composition of $\mathrm{Wo}_{4-2}$ (Fig. 10a). The orthopyroxene is mainly bronzite with characteristically higher $\mathrm{Mg}$ and $\mathrm{Cr}$ contents than in calc-alkaline basaltic andesite (Fig. 10b). Augite has Mg\# 69-73 and average composition of $\mathrm{Wo}_{40}$. Ishiyasumiba bronzite andesite has orthopyroxene with $\mathrm{Mg} \# 88$.
Olivine

Representative olivine compositions are presented in Table 4. Olivine from Koiji is $\mathrm{Fo}_{79-85}$ (Fig. 10c), with $\mathrm{NiO}=0.2 \mathrm{wt} . \%$. These values are lower than those of basalts reported from east Wajima (Uematsu et al., 1995).

\section{Spinel}

Spinel compositions are shown in Table 5. The spinels in the three series are also clearly distinguishable in the $\mathrm{Cr}-\mathrm{Al}^{-} \mathrm{Fe}^{3+}$ diagram (Fig. 11): $\mathrm{Cr}-$ poor $(\mathrm{Cr} \# \sim 0.49$ in 

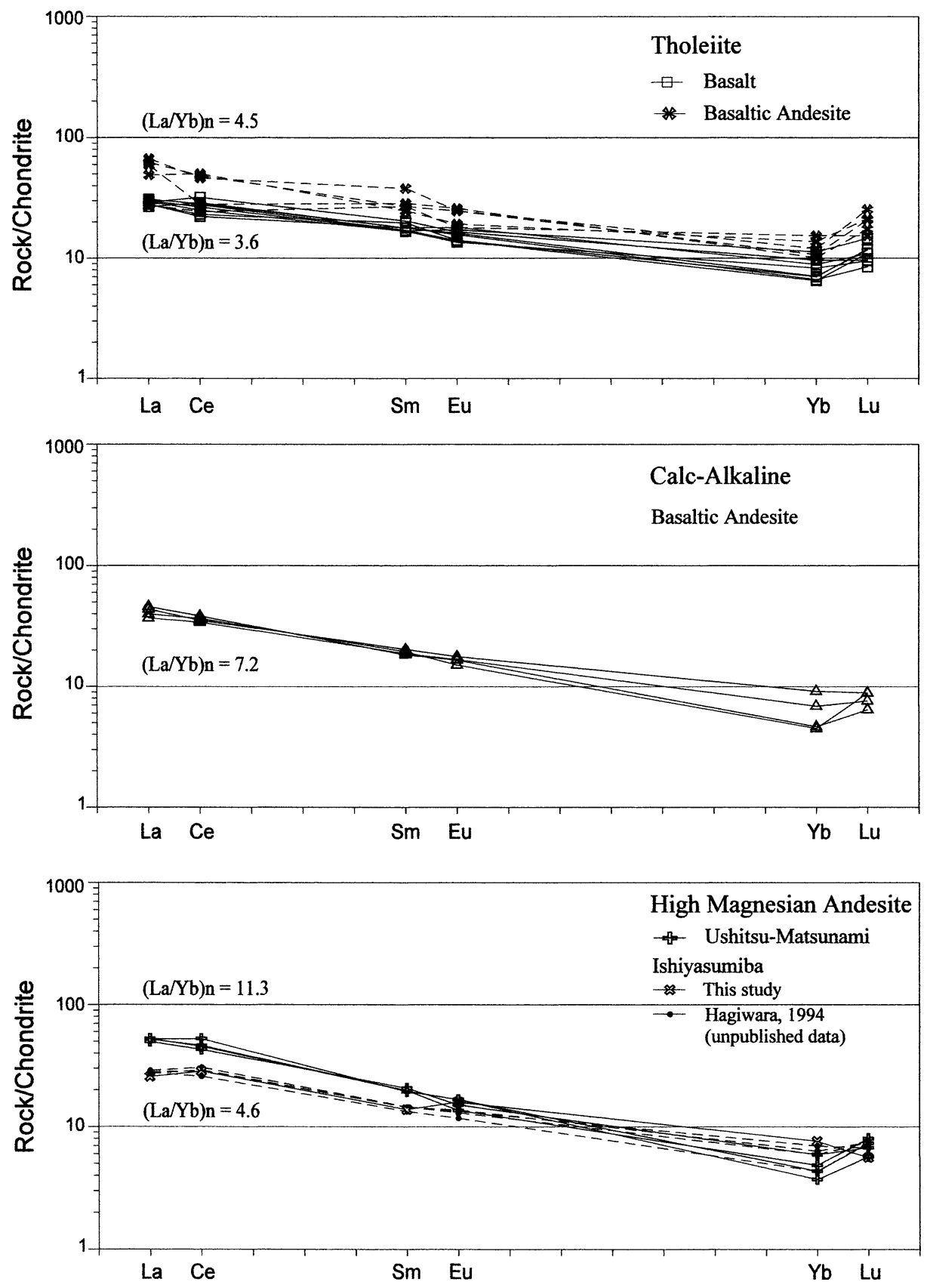

Figure 8. Chondrite normalized rare-earth element patterns for Anamizu Formation volcanic rocks. Chondrite values correspond to Leedey chondrite (Masuda et al., 1973). $(\mathrm{La} / \mathrm{Yb})_{\mathrm{n}}$ represents chondrite-normalized LREE/ HREE ratio. Ishiyasumiba data are from Hagiwara (unpublished) and this study.

basalt and $\sim 0.54$ in basaltic andesite) for the tholeiitic rocks, fairly $\mathrm{Cr}-$ rich $(\mathrm{Cr} \# \sim 0.61)$ for the calc-alkaline lavas, and $\mathrm{Cr}$-rich $(\mathrm{Cr} \# \sim 0.73)$ for the bronzite andesite (Ishiyasumiba, East Wajima). As the bronzite andesite of the Ushitsu-Matsunami area does not bear any spinel, another spinel-bearing bronzite andesite from Wajima area (Ishiyasumiba Quarry) is studied for comparison (unpublished data from Hagiwara, 1994; and this study), taking it as a representative of primitive highmagnesian andesite. Spinel compositions of HMA from Ishiyasumiba are comparable to those of Shodo Shima Island reported by Tatsumi and Ishizaka (1982a).
Spinels in all series rocks show $\mathrm{Fe}^{3+}$ and Ti enrichment in the course of fractional crystallization. The Nagao tholeiitic basalt lava bears very fractionated spinel, with high $\mathrm{Fe}^{3+} \#\left(\mathrm{Fe}^{3+} /\left(\mathrm{Cr}+\mathrm{Al}+\mathrm{Fe}^{3+}\right)\right) \sim 0.53$, although the bulk-rock $\mathrm{FeO}^{*} / \mathrm{MgO}$ is the lowest among tholeiitic basalt.

\section{Discussion}

\section{Tectonic setting}

$\mathrm{Sr}$ and $\mathrm{Nd}$ isotope studies of the Paleocene-Quaternary 
Table 3. Selected analysis of plagioclase and $\mathrm{K}$-feldspar phenocrysts from the Anamizu Formation lavas

\begin{tabular}{|c|c|c|c|c|c|c|c|}
\hline Series & THB & THB & THB & THB & THB & THB & THBA \\
\hline Mineral & $\mathrm{Pl}$ & $\mathrm{Pl}$ & $\mathrm{Pl}$ & $\mathrm{Pl}$ & Kspar & Kspar & $\mathrm{Pl}$ \\
\hline Sample & 981016 & 980513 & 981018 & 981030 & 981030 & 981030 & 980701 \\
\hline $\mathrm{SiO}_{2}$ & 53.21 & 53.24 & 53.39 & 53.24 & 65.30 & 66.79 & 52.60 \\
\hline $\mathrm{Al}_{2} \mathrm{O}_{3}$ & 29.09 & 28.77 & 29.03 & 28.63 & 19.07 & 18.88 & 28.19 \\
\hline $\mathrm{FeO}^{*}$ & 0.46 & 0.89 & 0.57 & 0.70 & 0.61 & 0.36 & 0.57 \\
\hline $\mathrm{MgO}$ & 0.02 & 0.01 & 0.00 & 0.00 & 0.03 & 0.01 & 0.00 \\
\hline $\mathrm{CaO}$ & 12.67 & 12.25 & 12.64 & 12.18 & 1.35 & 1.01 & 12.19 \\
\hline $\mathrm{Na}_{2} \mathrm{O}$ & 3.94 & 4.29 & 4.22 & 3.93 & 7.20 & 7.03 & 3.88 \\
\hline $\mathrm{K}_{2} \mathrm{O}$ & 0.23 & 0.24 & 0.29 & 0.27 & 5.15 & 5.31 & 0.21 \\
\hline Total & 99.66 & 99.76 & 100.21 & 99.14 & 98.88 & 99.48 & 97.67 \\
\hline $\mathrm{An} \%$ & 63.2 & 60.4 & 61.3 & 62.1 & 6.6 & 5.0 & 62.7 \\
\hline Or\% & 1.3 & 1.4 & 1.7 & 1.7 & 29.9 & 31.5 & 1.2 \\
\hline Series & THBA & THBA & CABA & CABA & CABA & HMA & HMA \\
\hline Mineral & $\mathrm{Pl}$ & $\mathrm{Pl}$ & $\mathrm{Pl}$ & $\mathrm{Pl}$ & $\mathrm{Pl}$ & $\mathrm{Pl}$ & $\mathrm{Pl}$ \\
\hline Sample & 980703 & 981022 & 980421 & 980718 & 981027 & 980709 & 981028 \\
\hline $\mathrm{SiO}_{2}$ & 52.84 & 49.26 & 53.71 & 54.54 & 54.90 & 54.77 & 54.77 \\
\hline $\mathrm{Al}_{2} \mathrm{O}_{3}$ & 29.71 & 29.15 & 28.21 & 28.56 & 28.50 & 27.86 & 28.34 \\
\hline $\mathrm{FeO}^{*}$ & 0.70 & 0.91 & 0.76 & 0.69 & 0.63 & 0.88 & 0.56 \\
\hline $\mathrm{MgO}$ & 0.00 & 0.00 & 0.00 & 0.00 & 0.00 & 0.25 & 0.17 \\
\hline $\mathrm{CaO}$ & 13.08 & 13.98 & 11.41 & 12.13 & 12.15 & 11.34 & 12.11 \\
\hline $\mathrm{Na}_{2} \mathrm{O}$ & 3.60 & 2.95 & 4.64 & 4.13 & 4.10 & 4.40 & 4.65 \\
\hline $\mathrm{K}_{2} \mathrm{O}$ & 0.12 & 0.11 & 0.35 & 0.29 & 0.30 & 0.23 & 0.18 \\
\hline Total & 100.25 & 96.36 & 99.24 & 100.45 & 100.74 & 99.91 & 100.83 \\
\hline $\mathrm{An} \%$ & 66.3 & 71.9 & 56.4 & 60.9 & 61.0 & 58.0 & 58.4 \\
\hline Or $\%$ & 0.7 & 0.7 & 2.1 & 1.7 & 1.8 & 1.4 & 1.0 \\
\hline
\end{tabular}

Each column represents average of 4 to 79 analyses in one rock specimen.

$\mathrm{Pl}$, plagioclase; Kspar, potassium feldspar; An\% $=100[\mathrm{Ca} /(\mathrm{Ca}+\mathrm{Na})]$; Or\% $=100[\mathrm{~K} /(\mathrm{Ca}+\mathrm{Na}+\mathrm{K})]$.

volcanic rocks from the Japan arc have shown a remarkable variation in trace element and isotopic compositions through the time, from enriched to depleted signatures. This trace element and isotopic variation may reflect the change of mantle source during the opening of the Japan Sea at $\sim 15 \mathrm{Ma}$ (Nohda and Wasserburg, 1986; Nohda et al., 1988; Tatsumi et al., 1989; Shuto et al., 1993; Shimazu et al., 1993; Ohki et al., 1994; Terakado et al., 1997). Before the opening stage, the subcontinental lithosphere within the mantle wedge was the principal source to produce magmas with an enriched isotopic signature. However, during the opening stage, a depleted source was formed possibly due to asthenospheric injection into the sub-continental lithosphere beneath the back arc side (Nohda and Wasserburg, 1986; Nohda et al., 1988; Tatsumi et al., 1989; Shuto et al., 1993; Ohki et al., 1994; Terakado et al., 1997).

Shimazu et al. (1993) and Uematsu et al. (1995) provided $\mathrm{Sr}$ and $\mathrm{Nd}$ isotope analysis of some Anamizu Formation andesites from Noto Peninsula. The Sr isotopic ratios are as high as those of the Green Tuff region from NE Japan (Nohda and Wasserburg, 1986; Nohda et al., 1988; Tatsumi et al., 1989; Shuto et al., 1993; Ohki et al., 1994), suggesting a volcanism produced before the opening of the Japan Sea, on an active continental margin (Shimazu et al., 1993).

On the other hand, the occurrence of non-marine sedimentary rocks (conglomerate, arkosic sandstone and mudstone) in the lower member, as well as the absence of pillow lavas in the upper member, may strongly indicate that the Anamizu Formation rocks were formed in a terrestrial environment. Other authors have also proposed similar conclusion for the same sequence exposed in different parts of Noto Peninsula (Ishida, 1959; Tanaka and Nozawa, 1977; Hoshina, 1984; Shimazu et al., 1993), and other localities around the Japan Sea (Okamura and Yoshida, 1989; Shimazu et al., 1993).

Moreover, all rocks of the three volcanic series in the studied area are depleted in HFSE such as $\mathrm{Nb}$ and 

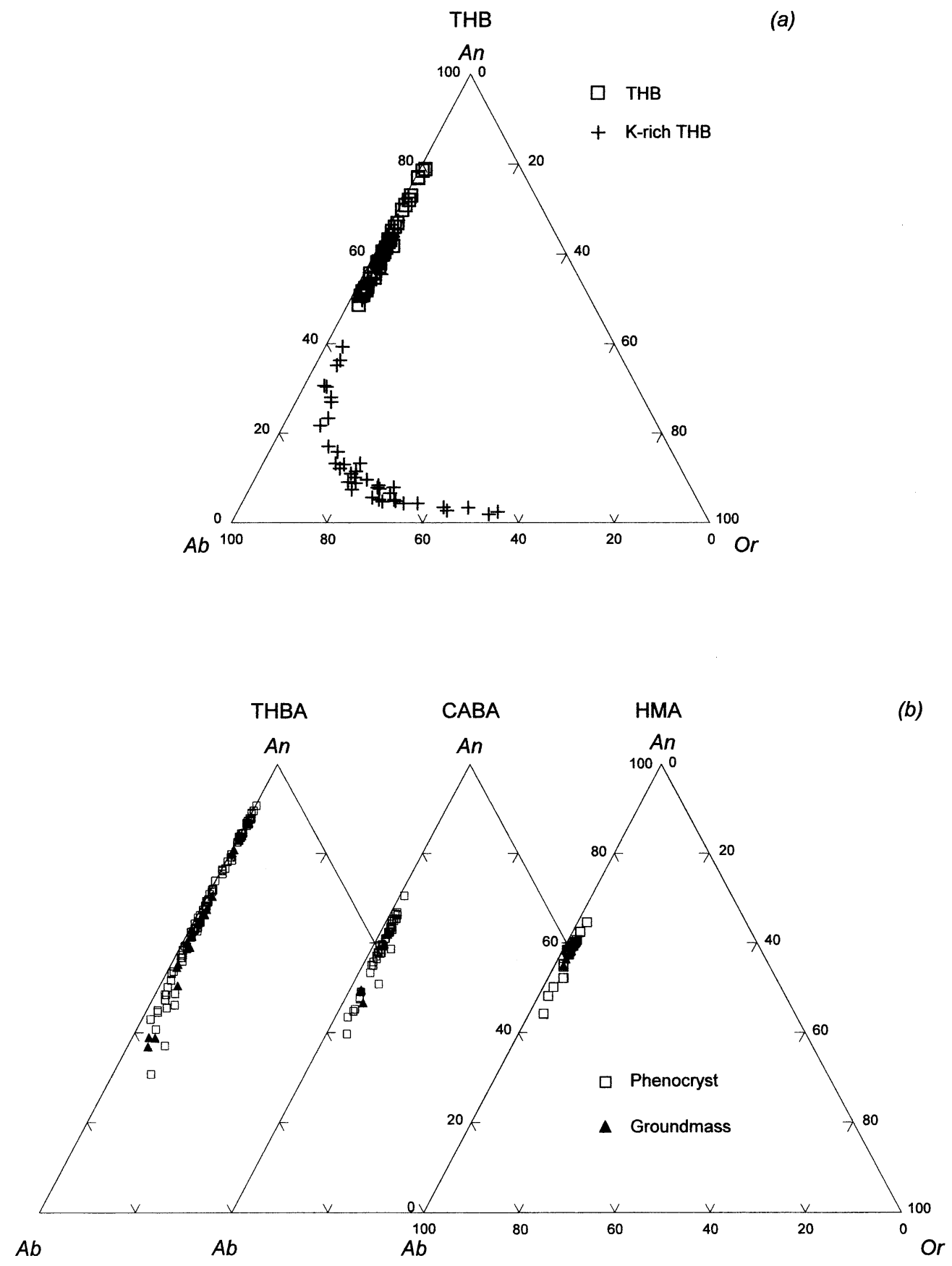

Figure 9. Plagioclase and potassium feldspar compositions of the Anamizu Formation volcanic rocks from UshitsuMatsunami area.

Ti compared with N-MORB and OIB (Fig. 7), suggesting typical subduction-related arc magmas (Pearce, 1982; 1983). It was also recognized that the basalts of the Anamizu Formation and that of the Iwaine Formation from Hokuriku Province (Ishiwatari and Ohama, 1997) contain higher $\mathrm{Zr} / \mathrm{Y}$ ratios than oceanic islandarc basalts (Fig. 12) like those in the Tonga (Wendt et al., 1997) and New Britain island arcs (Woodhead et al., 1998), but are similar to the typical active continental (a)

(b)

margin system like the South American Andes arc (Hickey et al., 1986). Therefore, in accordance with the preceding considerations, all the Anamizu volcanic series may be related to active continental margin magmatism.

\section{Considerations of magmatic sources}

Primary magmas formed from mantle peridotite are 


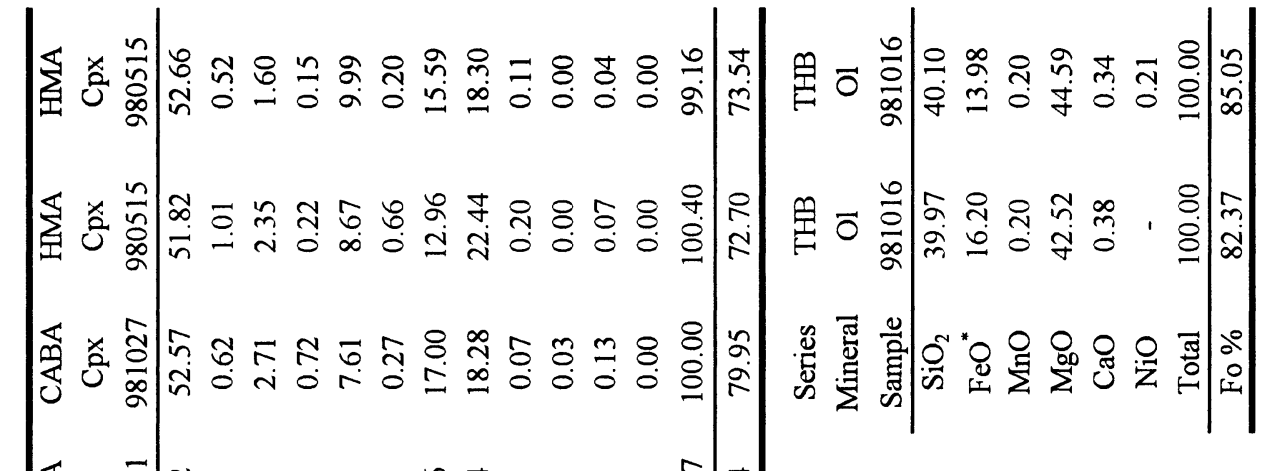

筞

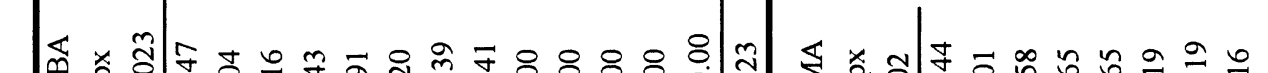

|

突

.

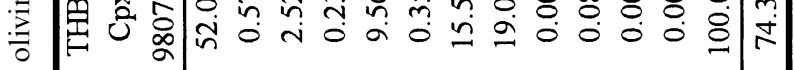

宊

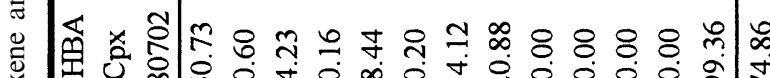

育

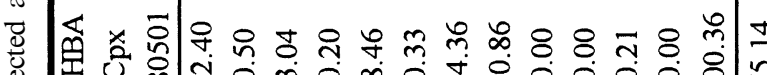

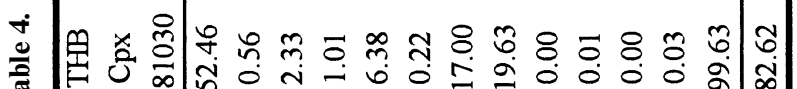

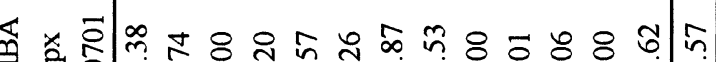

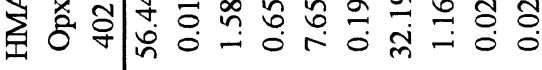

จ

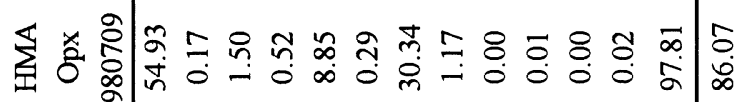

厸希

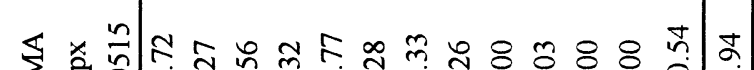

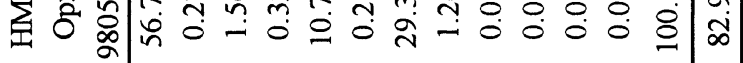

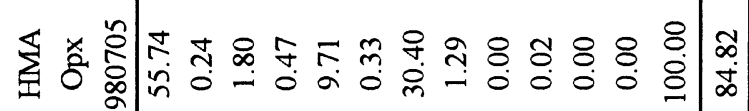

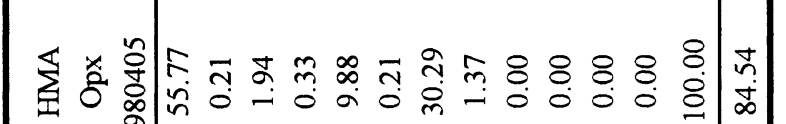

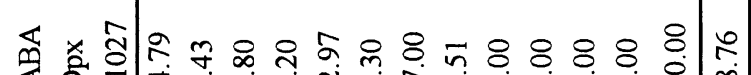

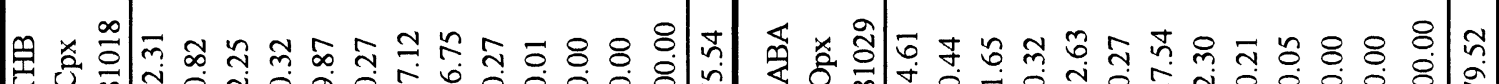

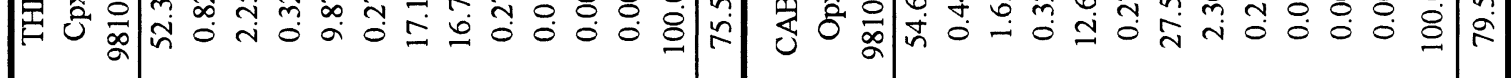

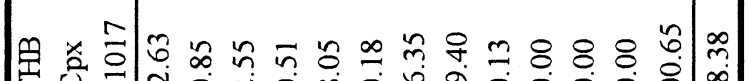

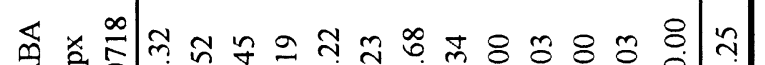
বु ठิ

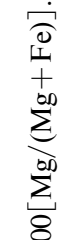

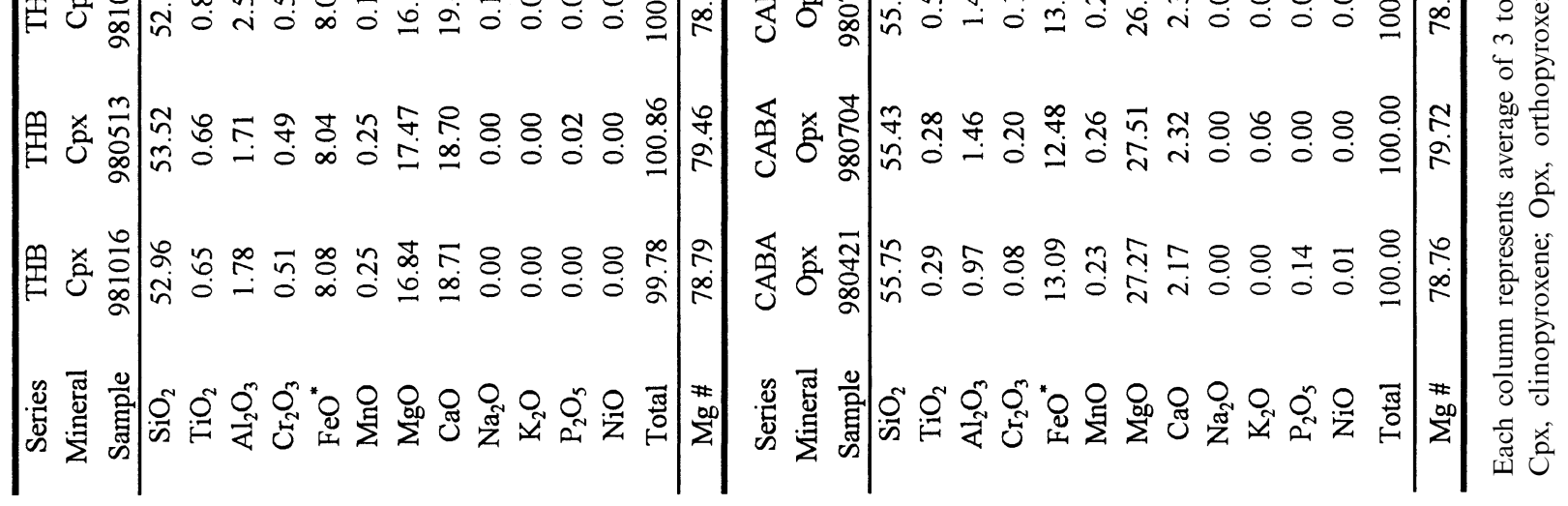



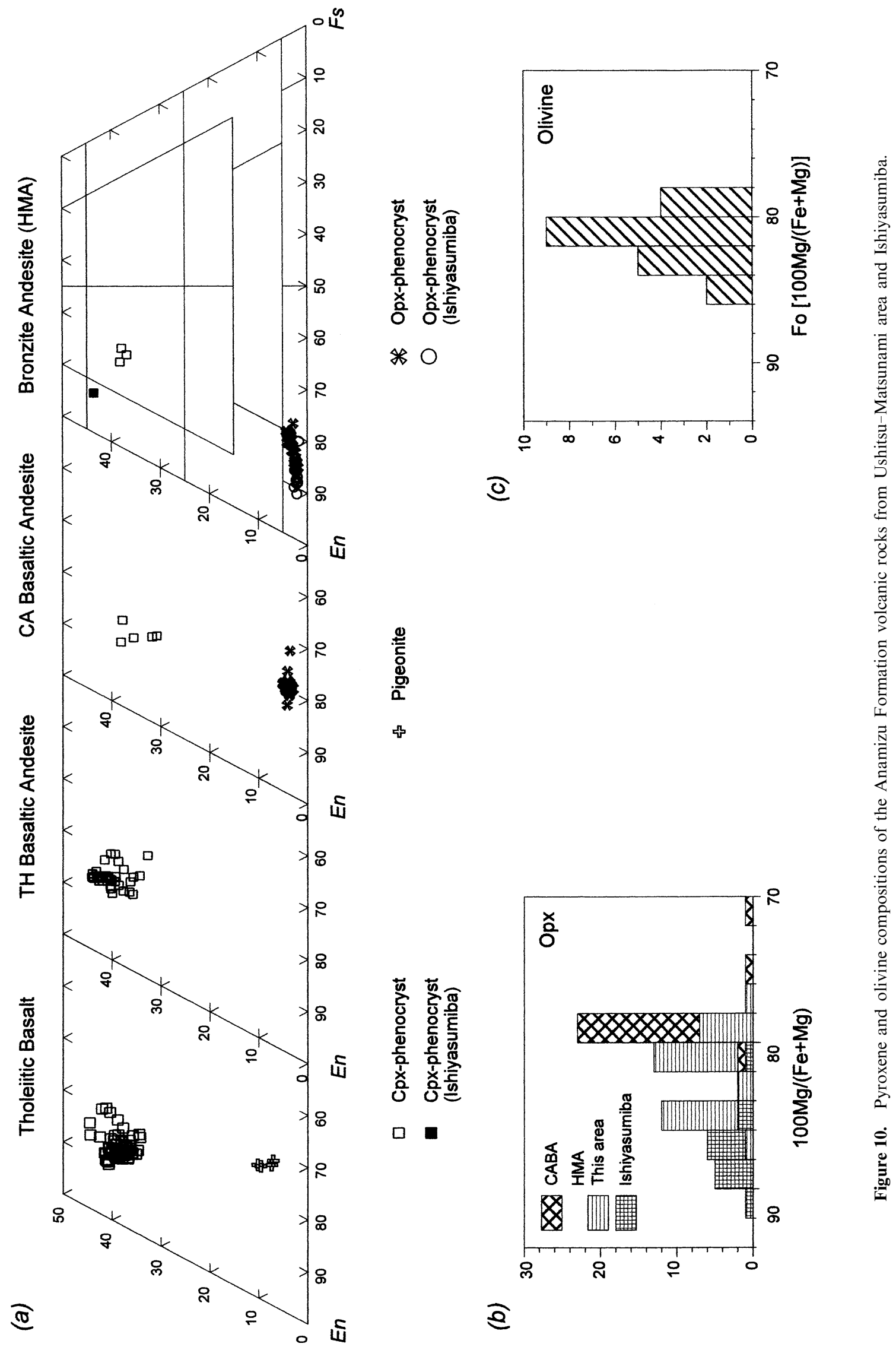
Table 5. Selected analysis of spinels

\begin{tabular}{|c|c|c|c|c|c|c|c|c|}
\hline Series & THB & THB & THB & THB & $\overline{\mathrm{THB}}$ & THB & THB & THB \\
\hline Sample & 980512 & 981016 & 981016 & 980513 & 981017 & 981017 & 981018 & 981018 \\
\hline $\mathrm{TiO}_{2}$ & 1.21 & 0.80 & 0.47 & 1.05 & 0.39 & 1.23 & 0.26 & 0.72 \\
\hline $\mathrm{Al}_{2} \mathrm{O}_{3}$ & 27.30 & 28.21 & 33.84 & 22.76 & 27.52 & 10.49 & 25.70 & 22.36 \\
\hline $\mathrm{Cr}_{2} \mathrm{O}_{3}$ & 34.54 & 33.45 & 28.96 & 31.71 & 33.43 & 36.48 & 31.27 & 33.39 \\
\hline $\mathrm{Fe}_{2} \mathrm{O}_{3}$ & 4.46 & 6.80 & 5.94 & 11.40 & 8.59 & 18.20 & 11.28 & 11.34 \\
\hline $\mathrm{FeO}$ & 21.78 & 18.65 & 16.42 & 24.44 & 18.53 & 27.81 & 23.61 & 25.06 \\
\hline $\mathrm{MnO}$ & 0.21 & 0.22 & 0.09 & 0.43 & 0.26 & 0.56 & 0.60 & 0.62 \\
\hline $\mathrm{MgO}$ & 9.96 & 11.97 & 13.77 & 7.39 & 11.76 & 3.74 & 7.98 & 6.87 \\
\hline Total & 99.47 & 100.10 & 99.48 & 99.18 & 100.47 & 98.52 & 100.69 & 100.36 \\
\hline $\mathrm{Cr} \#$ & 0.459 & 0.443 & 0.365 & 0.483 & 0.449 & 0.700 & 0.449 & 0.500 \\
\hline $\mathrm{Fe}^{3+} \#$ & 0.053 & 0.079 & 0.066 & 0.142 & 0.099 & 0.249 & 0.134 & 0.139 \\
\hline $\mathrm{Mg \#}$ & 0.449 & 0.534 & 0.599 & 0.350 & 0.531 & 0.193 & 0.376 & 0.328 \\
\hline Series & THB & THB & THBA & THBA & THBA & THBA & THBA & THBA \\
\hline Sample & 981030 & 981030 & 980703 & 980703 & 981022 & 981022 & 981023 & 981023 \\
\hline $\mathrm{TiO}_{2}$ & 0.34 & 0.18 & 0.69 & 0.56 & 1.30 & 13.66 & 0.73 & 13.10 \\
\hline $\mathrm{Al}_{2} \mathrm{O}_{3}$ & 7.45 & 7.08 & 25.95 & 2.70 & 23.67 & 5.41 & 22.76 & 4.95 \\
\hline $\mathrm{Cr}_{2} \mathrm{O}_{3}$ & 30.62 & 31.68 & 25.64 & 9.95 & 22.71 & 12.41 & 35.77 & 7.03 \\
\hline $\mathrm{Fe}_{2} \mathrm{O}_{3}$ & 29.49 & 28.66 & 16.12 & 56.85 & 19.03 & 23.85 & 11.02 & 30.93 \\
\hline $\mathrm{FeO}$ & 29.11 & 28.74 & 26.20 & 28.83 & 26.50 & 42.22 & 18.49 & 40.43 \\
\hline $\mathrm{MnO}$ & 0.24 & 0.38 & 0.30 & 0.36 & 0.28 & 0.41 & 0.26 & 0.56 \\
\hline $\mathrm{MgO}$ & 2.38 & 2.28 & 6.96 & 2.24 & 6.47 & 1.31 & 11.48 & 1.84 \\
\hline Total & 99.63 & 98.99 & 101.86 & 101.50 & 99.96 & 99.27 & 100.50 & 98.85 \\
\hline $\mathrm{Cr} \#$ & 0.734 & 0.750 & 0.399 & 0.712 & 0.392 & 0.606 & 0.513 & 0.488 \\
\hline $\mathrm{Fe}^{3+} \#$ & 0.402 & 0.392 & 0.193 & 0.795 & 0.238 & 0.526 & 0.131 & 0.671 \\
\hline $\mathrm{Mg \#}$ & 0.127 & 0.124 & 0.321 & 0.122 & 0.303 & 0.052 & 0.525 & 0.075 \\
\hline Series & $\mathrm{CABA}$ & $\mathrm{CABA}$ & $\mathrm{CABA}$ & CABA & HMA & HMA & & \\
\hline Sample & 980421 & 980421 & 981029 & 981029 & 402 & 402 & & \\
\hline $\mathrm{TiO}_{2}$ & 1.28 & 13.58 & 1.40 & 1.52 & 0.23 & 0.24 & & \\
\hline $\mathrm{Al}_{2} \mathrm{O}_{3}$ & 20.43 & 5.75 & 19.62 & 16.78 & 11.74 & 10.95 & & \\
\hline $\mathrm{Cr}_{2} \mathrm{O}_{3}$ & 40.05 & 22.71 & 38.99 & 38.88 & 46.62 & 46.85 & & \\
\hline $\mathrm{Fe}_{2} \mathrm{O}_{3}$ & 6.43 & 14.10 & 8.04 & 9.83 & 11.22 & 11.21 & & \\
\hline $\mathrm{FeO}$ & 22.68 & 38.64 & 21.60 & 23.67 & 17.78 & 18.13 & & \\
\hline $\mathrm{MnO}$ & 0.19 & 0.47 & 0.23 & 0.18 & 0.41 & 0.46 & & \\
\hline $\mathrm{MgO}$ & 8.78 & 3.61 & 9.29 & 7.58 & 9.86 & 9.39 & & \\
\hline Total & 99.83 & 98.87 & 99.17 & 98.44 & 97.86 & 97.23 & & \\
\hline $\mathrm{Cr} \#$ & 0.568 & 0.726 & 0.571 & 0.608 & 0.727 & 0.742 & & \\
\hline $\mathrm{Fe}^{3+} \#$ & 0.080 & 0.300 & 0.101 & 0.128 & 0.143 & 0.144 & & \\
\hline $\mathrm{Mg \#}$ & 0.408 & 0.143 & 0.434 & 0.363 & 0.497 & 0.480 & & \\
\hline
\end{tabular}

Each column represents average of 9 to 45 analyses in one rock specimen.

$\mathrm{Cr} \#=\mathrm{Cr} /(\mathrm{Cr}+\mathrm{Al}) ; \mathrm{Fe}^{3+} \#=\mathrm{Fe}^{3+} /\left(\mathrm{Cr}+\mathrm{Al}+\mathrm{Fe}^{3+}\right) ; \mathrm{Mg} \#=\mathrm{Mg} /\left(\mathrm{Mg}+\mathrm{Fe}^{2+}\right)$.

thought to have $\mathrm{Mg}$ \# values at 70 or higher (Green et al., 1974). Nevertheless, all three volcanic series from Ushitsu-Matsunami area have $\mathrm{Mg}$ \# values lower than 60 as well as fractionated olivine composition (low forsterite number, av. $\mathrm{Fo}_{81}$ ); suggesting extensive frac- tional crystallization of the parental magma before eruption. Furthermore, tholeiitic, calc-alkaline and bronzite andesite series contain lower $\mathrm{Ni}(<200 \mathrm{ppm})$ and $\mathrm{Cr}$ concentrations than those rocks representing primitive magmas, which have $\mathrm{NiO}$ content of $300-500$ 


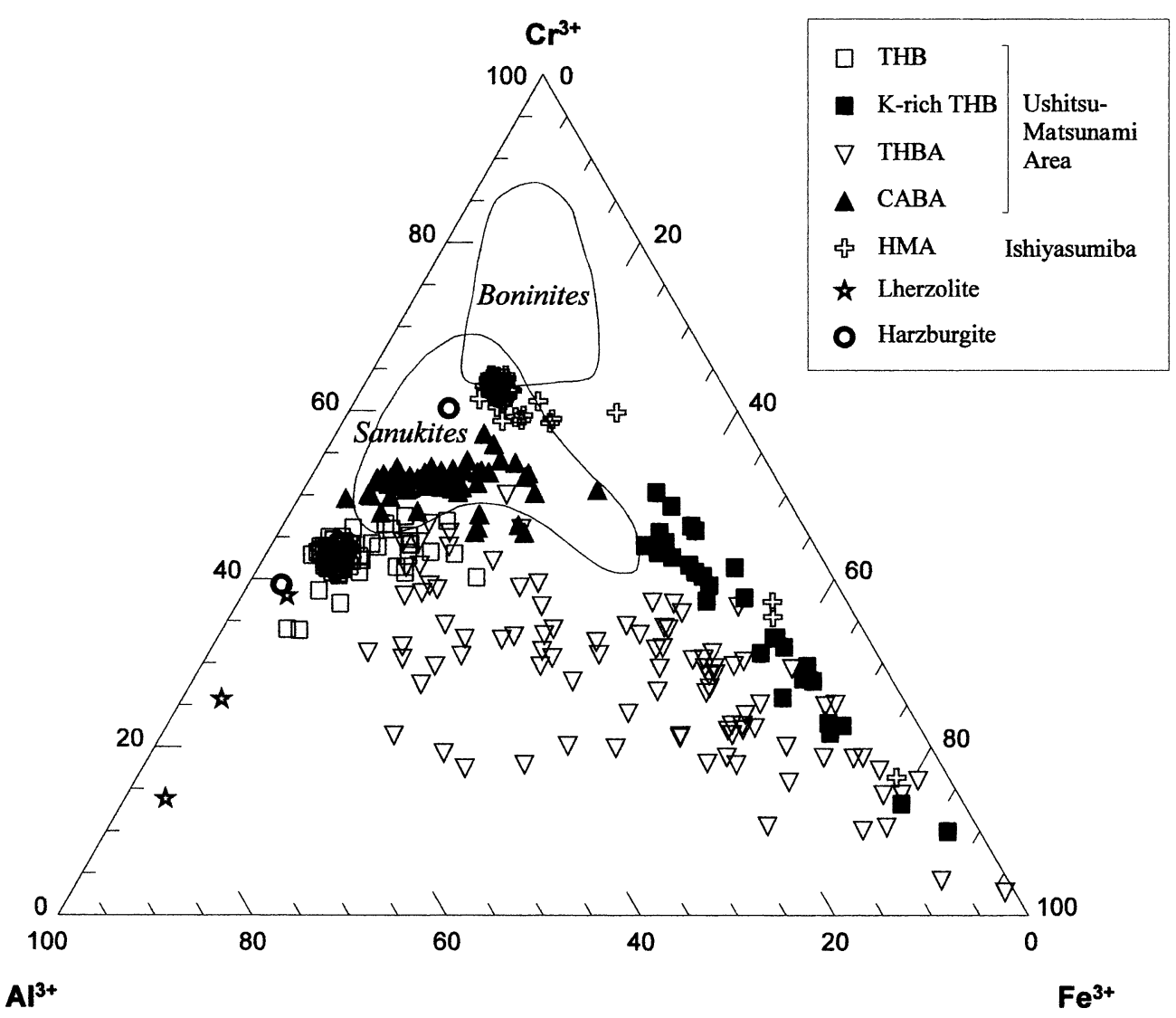

Figure 11. Chemical compositions of spinel inclusions in olivine of tholeiitic and calc-alkaline rocks and bronzite phenocrysts of bronzite andesite, respectively. The spinel-bearing bronzite andesite is from Ishiyasumiba, east of Wajima (unpublished data from Hagiwara, 1994, and this study). The field of high-magnesian andesite (HMA) is after Tatsumi and Ishizaka (1982a) (Shodo-Shima Island). Lherzolite and harzburgite data are from Arai et al. (2000).

ppm (Sato, 1977). Besides, the lower NiO content (less than 0.2 wt.\%) of olivine in the tholeiitic basalt than that estimated for olivine from primary basaltic magma $(0.4$ wt.\%, after Sato, 1977) also suggest a more fractionated magma for the tholeiitic rocks. Therefore, all three volcanic series represent evolved magmas.

Bronzite andesite from Ushitsu-Matsunami area has some mineralogical and geochemical differences with other bronzite andesite reported from central Noto Peninsula and HMA of the Setouchi area (Tatsumi and Ishizaka, 1981; 1982a; 1982b). Bronzite andesites from east Wajima (Uematsu et al., 1995) and around Yanagida (Hoshina, 1984; Shimazu et al., 1993) have distinctive mineral assemblage of (olivine-) orthopyroxene-clinopyroxene with spinel inclusions, and without plagioclase as phenocrystic phase, in contrast to the spinel-free plagioclase-orthopyroxene-clinopyroxene assemblage found in this study. Moreover, bronzite andesite from east Wajima (Ishiyasumiba) is higher in $\mathrm{MgO}, \mathrm{CaO}, \mathrm{FeO}^{*}$ and in compatible elements like $\mathrm{Ni}$ and $\mathrm{Cr}$ than bronzite andesite from this area. This particularity indicates less evolved and more primitive nature of the bronzite andesite from Ishiyasumiba. Lower LILE contents of this lava, especially very low $\mathrm{Rb}$, may also be largely due to its less evolved nature, but its relative enrichment in HREE suggest slightly less depleted and less metasomatized source than that of the Ushitsu-Matsunami area (Figs. 7, 8 and Table 2).

In HMA rocks from the Setouchi area, phenocrystic plagioclase is absent or can be present as a subordinate phase, whereas bronzite is a more important phenocrystic phase crystallizing after olivine (Tatsumi and Ishizaka, 1982b), which is almost absent in the UshitsuMatsunami bronzite andesites. Moreover, Setouchi volcanic rocks contain higher concentrations of $\mathrm{MgO}$, $\mathrm{Ni}$ and $\mathrm{Cr}$, and exhibit a less evolved REE pattern with slight enrichment of LREE. These differences reveal a more primitive parental magma and less metasomatized source mantle for the HMA of Setouchi area. These considerations also show that the bronzite andesite magma of the Ushitsu-Matsunami area is evolved. 


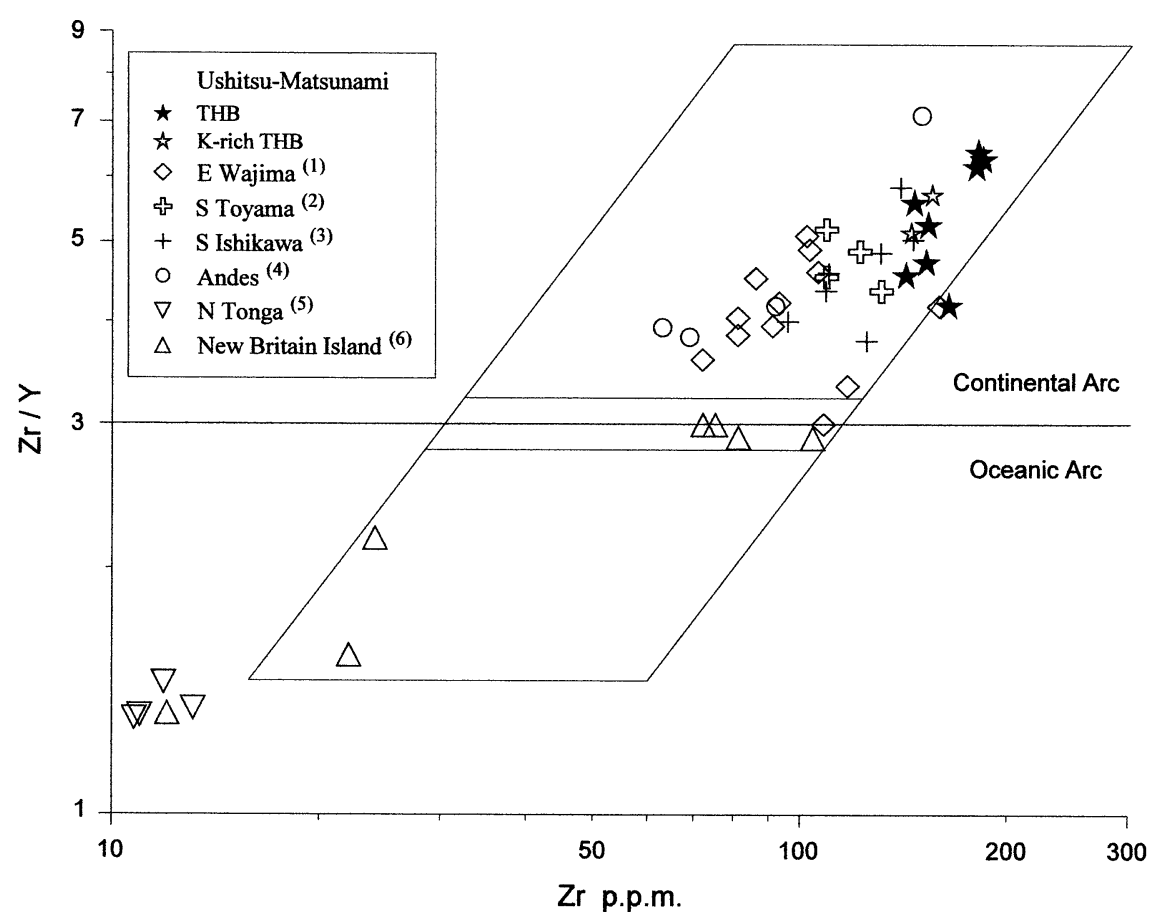

Figure 12. Tectono-magmatic setting of basaltic rocks from Noto Peninsula and Toyama areas, comparing with other volcanic arcs (diagram after Pearce, 1983). References are (1) Uematsu et al., 1995 (2) Takahashi and Shuto, 1999 (3) Ishiwatari and Ohama, 1997 (4) Hickey et al., 1986 (5) Wendt et al., 1997 (6) Woodhead et al., 1998.

\section{Fractional crystallization or difference in the source}

Tholeiitic basaltic andesite has lower $\mathrm{Mg}$ \# values than calc-alkaline basaltic andesite and bronzite andesite. This relation may reflect the more extensive olivine fractionation in tholeiitic basalt. Different composition of the parental source might also explain these $\mathrm{Mg} \#$ variations. If a common parental magma is considered to be the source of all three volcanic series, it can not explain the higher $\mathrm{MgO}, \mathrm{Ni}$ and $\mathrm{Cr}$ contents of calcalkaline basaltic andesite and bronzite andesite in comparison with tholeiitic basaltic andesite.

Calc-alkaline basaltic andesite and bronzite andesite exhibit some similarities in $\mathrm{Y}$ and $\mathrm{Nb}$ contents, but tholeiitic basaltic andesite has distinctly higher values. Both calc-alkaline basaltic andesite and bronzite andesite have higher enrichment of LREE in relation to HREE, i.e., higher LREE/HREE ratios (La/ $\mathrm{Yb})_{\mathrm{n}}$ (7.2 in the former and 11.3 in the latter) than tholeiitic rocks showing a distinctive enrichment in HREE, hence, lower $(\mathrm{La} / \mathrm{Yb})_{\mathrm{n}}$ ratio (basalt: 3.6; basaltic andesite: 4.5) (Fig. 8).

Orthopyroxene compositions of calc-alkaline basaltic andesite and bronzite andesite show a clear difference in $\mathrm{Mg}$ and $\mathrm{Cr}$ contents (Fig. 13a). The bronzite andesite has higher $\mathrm{Mg} \#$ and $\mathrm{Cr} \#$ than the former. Therefore, fractional crystallization of calcalkaline basaltic andesite magma could not produce bronzite andesite containing $\mathrm{Mg}^{-}$and $\mathrm{Cr}$-rich orthopyroxene. In the case of HMA, even though bronzite andesite from the Ushitsu-Matsunami area has orthopyroxene with lower $\mathrm{Mg} \#$ and $\mathrm{Cr} \#$ than those of Ishiyasumiba, the least evolved end-member of the high- magnesian andesite reported in Noto Peninsula, the orthopyroxene from the two areas form a single fractionation trend in the $\mathrm{Mg} \#-\mathrm{Cr} \#$ diagram (Fig. 13a), suggesting high $\mathrm{Cr} \#$ of coexisting spinel in a more primitive, unexposed magma of the Ushitsu-Matsunami HMA.

Spinel compositions of all the lava series also exhibit three different trends (as it was already shown before), from $\mathrm{Al}$-rich for tholeiitic rocks to $\mathrm{Cr}$-rich for HMA (Ishiyasumiba). These features suggest a gradual depletion or increasing degree of partial melting of the mantle source.

In the case of tholeiitic basalt, even though $\mathrm{K}$-rich basalt from Nagao area contains very fractionated spinel $\left(\mathrm{Fe}^{+3}\right.$-rich), it is different from primitive spinels in the $\mathrm{K}$ - poor basalt (Fig. 11), the bulk $\mathrm{MgO}, \mathrm{Cr}$ and $\mathrm{Ni}$ contents of the former are higher than some of the latter (Onozaki and Oosawa Creek) (Figs. 5 and 6). This precludes a common origin of these rocks by simple fractional crystallization from the same primitive magma. Instead, the fractionation of heterogeneous parental source may account for such contrasting mineralogy and rock chemistry.

On the other hand, in the bulk rock $\mathrm{TiO}_{2}-\mathrm{FeO}^{*}$ / $\mathrm{MgO}$ diagram (Fig. 4b), two different trends can be easily distinguished: a high- $\mathrm{TiO}_{2}$ for tholeiitic rocks and low- $\mathrm{TiO}_{2}$ for bronzite andesite, whereas calc-alka- 
(a)

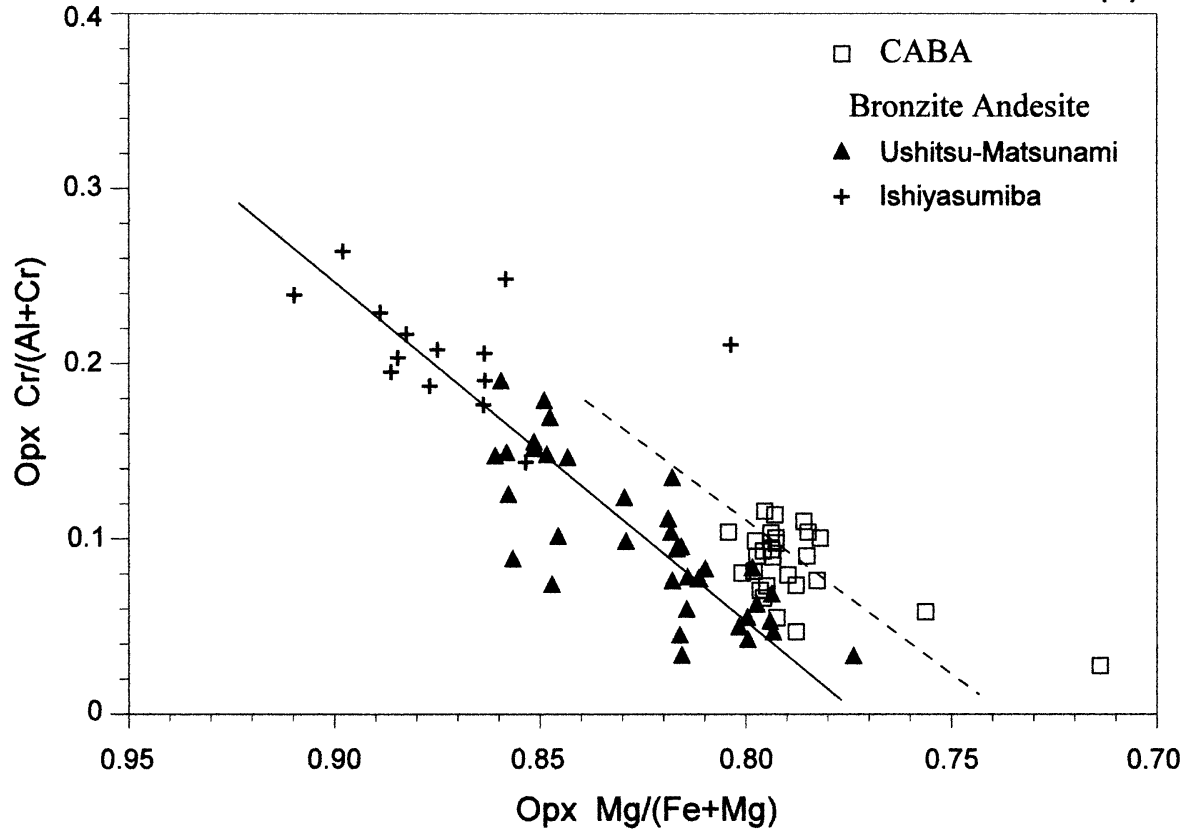

(b)

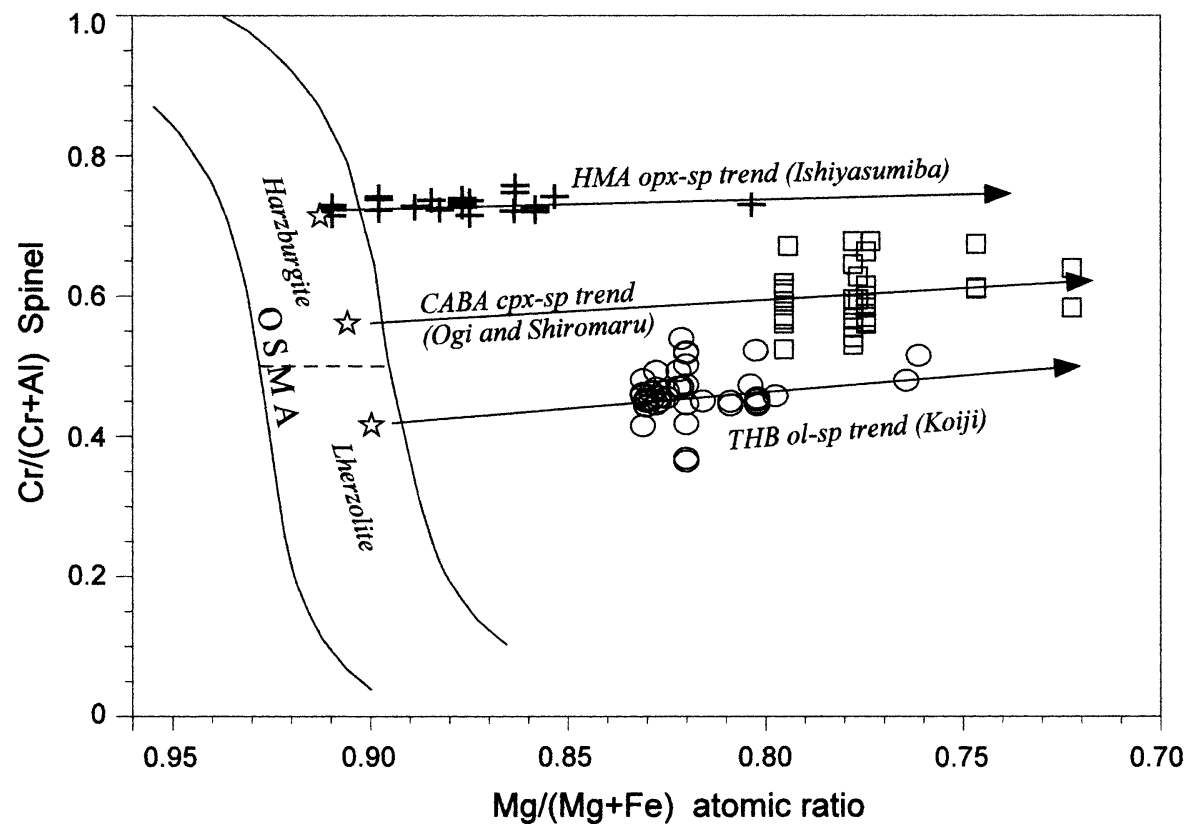

Figure 13. a) Orthopyroxene $\mathrm{Mg} \#(\mathrm{Mg} /(\mathrm{Mg}+\mathrm{Fe}))$ vs. $\mathrm{Cr} \#$ $(\mathrm{Cr} /(\mathrm{Cr}+\mathrm{Al}))$ diagram of calcalkaline basaltic andesite (CABA) and bronzite andesites from Ishiyasumiba and UshitsuMatsunami area. b) Relationships of olivine and orthopyroxene $\mathrm{Mg} \#(\mathrm{Mg} /(\mathrm{Mg}+\mathrm{Fe}))$ vs. spinel $\mathrm{Cr} \# \quad(\mathrm{Cr} /(\mathrm{Cr}+\mathrm{Al}))$ of tholeiitic basalt (THB) and highmagnesian andesite (HMA) from the Anamizu Formation (after Arai, 1987; 1994). In CABA, cpx $\mathrm{Mg}$ \# has been used due to the absence of fresh spinel-bearing olivine.

line basaltic andesite trend is in between, containing slightly lower $\mathrm{TiO}_{2}$ contents than tholeiitic basalt. These variations in $\mathrm{TiO}_{2}$ compositions may suggest a $\mathrm{TiO}_{2}$-impoverishment of the parental source from tholeiite to bronzite andesite.

These compositional changes can not be explained by crystal fractionation of a common parental magma. Variations of bulk HFSE, Ni and $\mathrm{Cr}$ compositions may indicate a progressive depletion or increasing degree of partial melting of the mantle source in the order tholeiite $\rightarrow$ calc-alkaline $\rightarrow$ bronzite andesite. Nevertheless, LILE and LREE, on the contrary, exhibit a gradual enrichment of the source in the same order as already noted above.

\section{Petrogenetic relationship}

$\mathrm{TiO}_{2}$ (HFSE) and $\mathrm{K}_{2} \mathrm{O}$ (LILE) are generally incompatible during partial melting and early crystallization processes. Therefore, the $\mathrm{TiO}_{2} / \mathrm{K}_{2} \mathrm{O}$ ratio of the most 


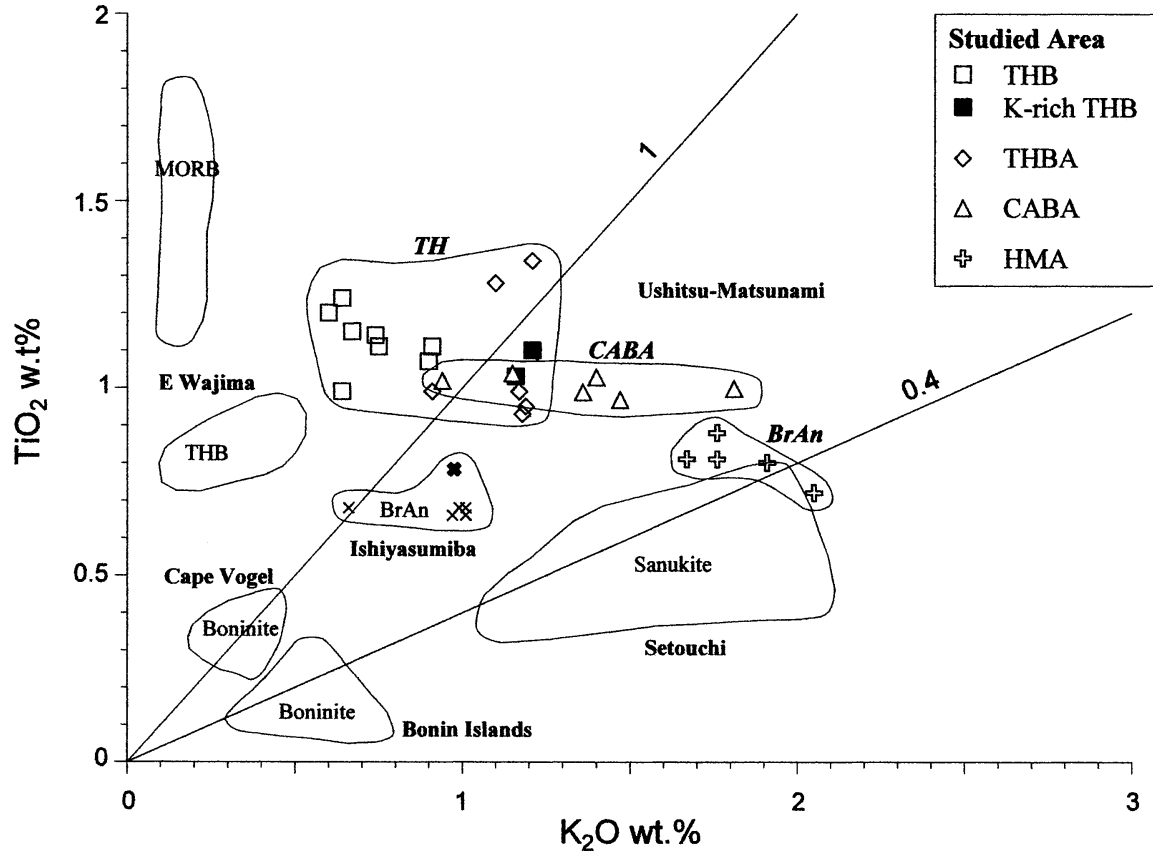

Figure 14. $\mathrm{TiO}_{2}-\mathrm{K}_{2} \mathrm{O}$ diagram of the Anamizu Formation volcanic series. Lower $\mathrm{TiO}_{2} / \mathrm{K}_{2} \mathrm{O}$ ratios may represent infiltration of water in the parental magma (Tatsumi and Ishizaka, 1982b; Okamura and Yoshida, 1989). Cape Vogel and Bonin Islands boninites after Hickey and Frey (1982), Setouchi sanukites after Tatsumi and Ishizaka (1982b), Ishiyasumiba bronzite andesite after Hagiwara (thin cross; unpublished) and this study (thick cross), E Wajima after Uematsu et al. (1995), MORB after Melson et al. (1976). primitive rocks may indicate values close to their magma source. Increasing degree of mantle metasomatism by fluids coming from the subducted slab may add more $\mathrm{K}_{2} \mathrm{O}$ than $\mathrm{TiO}_{2}$ to the mantle, because $\mathrm{K}_{2} \mathrm{O}$ is more soluble in water-rich fluids than $\mathrm{TiO}_{2}$. On the other hand, successive melting of the mantle source and melt extraction may reduce the $\mathrm{TiO}_{2}$ content. Both processes will decrease the $\mathrm{TiO}_{2} / \mathrm{K}_{2} \mathrm{O}$ ratio of the liquid (Tatsumi and Ishizaka, 1982b; Okamura and Yoshida, 1989).

All three volcanic series rocks are plotted in the $\mathrm{K}_{2} \mathrm{O}-\mathrm{TiO}_{2}$ diagram (Fig. 14). Two different endgroups can be observed: tholeiitic rocks having higher ratios $(\geq 1$, excepting Nagao tholeiitic basalt and the lower lava of Fukugami, which have ratios $<1$ ), and bronzite andesite with lower ratios (around 0.4), whereas calc-alkaline basaltic andesite exhibits values between tholeiitic basaltic andesite and bronzite andesite. Therefore, tholeiitic and high-magnesian andesite series may have derived from different primary magmas, under anhydrous and hydrous conditions, respectively. However, the K-rich tholeiitic basalt from Nagao and Fukugami lower lava may suggest a slight metasomatism in the tholeiitic source mantle. Nevertheless, there are strong differences in concentrations of major elements $(\mathrm{MgO}$ and $\mathrm{FeO}), \mathrm{FeO}^{*} / \mathrm{MgO}-\mathrm{TiO}_{2}$ ratios and trace elements ( $\mathrm{Y}, \mathrm{Nb}, \mathrm{Cr}, \mathrm{Ni}$ and REEs) among the three series. This relation precludes a common derivation from the same parental magma only by fractional crystallization.

The low water in the primitive tholeiitic magmas is also suggested by the absence of hydrous mineral like hornblende or biotite (or phlogopite) in the evolved tholeiitic basaltic andesite. However, Ca-rich plagioclase in arc magmas has been referred as a consequence of the presence of water in the primary magma (Yoder, 1969; Johannes, 1978; Sisson and Grove, 1993a; 1993b). It will lower the solidus temperature and permit the crystallization of calcic plagioclase. According to the previous consideration, $\mathrm{Ca}$-rich plagioclase in tholeiitic basaltic andesite may reflect the slight introduction of water into the magma during the course of fractional crystallization.

Mysen (1979) has suggested that the enrichment in LREE of magmas formed in the mantle wedge indicate the addition of fluid phases equilibrated with garnet in the underlying slab. In addition, LILE-enrichment in island-arc source was considered as a consequence of incoming of incompatible lithophile elements with larger ionic radii (LILE) through fluid phases derived from of the descending slab (Tatsumi, 1991).

According to the previous considerations, the enrichment in LILE and LREE in calc-alkaline basaltic andesite, bronzite andesite, and the $\mathrm{K}$-rich tholeitiic rocks (Nagao and Fukugami lower lava) may be produced by similar process. It is also in harmony with hydrous conditions suggested from their low $\mathrm{TiO}_{2} / \mathrm{K}_{2} \mathrm{O}$ ratios.

\section{Composition of the mantle source}

Spinel composition can be used as an important petrogenetic tool to know the chemical characteristics of 
its parental magma or mantle source. Olivine Fo and spinel $\mathrm{Cr} \#$ of mantle restites, in equilibrium with primary magmas, can be estimated by extrapolating the $\mathrm{Fo}^{-} \mathrm{Cr}$ \# trend back to the olivine-spinel mantle array, or OSMA (Arai, 1987; 1994a).

Experiments of mantle melting to produce highmagnesian andesite under hydrous conditions showed that olivine and orthopyroxene can coexist on the liquidus (Kushiro, 1974; Tatsumi, 1981; Kushiro, 1990; Hirose, 1997). As it was already noted, $\mathrm{Mg}$-rich orthopyroxene represents an important phenocrystic phase in bronzite andesite, while clinopyroxene is dominant in calc-alkaline basaltic andesite. Consequently, it may be reasonable that each of the two pyroxenes may have been in equilibrium with olivine during crystallization of the respective magmas. It is well known that $\mathrm{Cr} \#$ of spinel decreases collaterally with increase of $\mathrm{Al}_{2} \mathrm{O}_{3}$ (and decrease of $\mathrm{Cr} \#$ ) of coexisting pyroxenes among mantle peridotites (Dick, 1977; Ishiwatari, 1985).

To estimate spinel $\mathrm{Cr}$ \# of the mantle restite of the three magma series, the relation between olivine and spinel is used for tholeiitic basalt, clinopyroxene and spinel for calc-alkaline basaltic andesite and orthopyroxene and spinel for bronzite andesite (Fig. 13b). In the case of calc-alkaline basaltic andesite, clinopyroxene has been used due to the absence of fresh olivine or spinel bearing $\mathrm{Mg}$-rich orthopyroxene.

Spinel compositions from the less fractionated tholeiitic basalt and calc-alkaline basaltic andesite in the area lie far away from the olivine-spinel mantle array, revealing an evolved nature of these two volcanic series. If these spinel composition trends are extrapolated back to their parental magma, which can coexist with olivinespinel pairs within the OSMA field, these trends will indicate different mantle restites: a lherzolite with $\mathrm{Cr} \#$ of $\sim 0.4$ for the tholeiitic basalt and a harzburgitic restite with $\mathrm{Cr} \#$ of $\sim 0.55$ for the calc-alkaline basaltic andesite. The orthopyroxe-spinel pairs in bronzite andesite of Ishiyasumiba (east Wajima) closely approach to the OSMA field, and indicate harzburgite restite with spinel $\mathrm{Cr} \# \sim 0.7$ (Fig. 13b). As bronzite andesite from Ushitsu-Matsunami area represents fractionated rocks following similar orthopyroxene $\mathrm{Mg} \#-\mathrm{Cr} \#$ trend to those of Ishiyasumiba, and has higher $\mathrm{Mg} \#-\mathrm{Cr} \#$ than CABA (Fig. 13a), this rocks may also suggest a harzburgite restite having high $\mathrm{Cr} \#$ spinel alike to Ishiyasumiba's.

Shukuno and Arai (1999) and Arai et al. (2000) suggested heterogeneous upper mantle (lherzolite and harzburgite) beneath the Southwest Japan arc based on compositions of olivine-spinel from Cenozoic alkali basalts and peridotite xenoliths.

\section{Origin of Volcanic Series}

Geological survey of the lava succession in the UshitsuMatsunami area reveals that the upper member of the Anamizu formation contains three different volcanic series that exhibit a chronological magmatic succession from tholeiite $\rightarrow$ calc-alkaline $\rightarrow$ bronzite andesite. It is clear from the preceding discussion that tholeiitic basalt, calc-alkaline basaltic andesite and bronzite andesite from Ushitsu-Matsunami were derived from three different parental magmas. Therefore, the tholeiitic magma was formed first by partial melting of the upper mantle wedge (lherzolite), under almost anhydrous conditions and higher temperatures, more than $1200^{\circ} \mathrm{C}$ (Gill, 1981; Fujinawa, 1988; Uematsu et al., 1995) (Fig. 15a). As the $\mathrm{K}$-rich basalt represent the most primitive tholeiitic basalt (lowest $\mathrm{FeO}^{*} / \mathrm{MgO}$ ratio) but comparatively rich in LILE and fractionated spinel, it may be produced from another mantle source (slightly metasomatized lherzolite) under slightly hydrous conditions. The bronzite andesite magma was produced by partial melting of the hydrous and highly metasomatized mantle source (harzburgite) at lower temperatures, less than $1100^{\circ} \mathrm{C}$ (Kushiro, 1974; Tatsumi and Ishizaka, 1981; Hickey and Frey, 1982; Tatsumi, 1991; Hirose, 1997) during the last stage (Fig. 15b). Taking into consideration that the order of the lava succession in the studied area is tholeiite $\rightarrow$ calc-alkaline $\rightarrow$ bronzite andesite (Fig. 15b), the calc-alkaline rocks may have originated from a different parental magma derived from a harzburgite mantle under moderately hydrous conditions, after the tholeiite generation. In the case of the calc-alkaline and bronzite andesite series, influx of hydrous fluids may be important to lower the solidus temperature of the "refractory" mantle source and permit partial melting. The source of the high temperatures required to permit melting of the "refractory" mantle wedge may be produced by asthenospheric injection into the sub-continental lithosphere, previous to and during the opening of the Japan Sea.

\section{Conclusions}

1. The upper member of the Oligo-Miocene Anamizu Formation exposed in the Ushitsu-Matsunami area includes three lava series: tholeiite, calc-alkaline and high magnesian andesite, in ascending order.

2. Relative abundance of trace elements, especially low $\mathrm{Ti}, \mathrm{Nb}, \mathrm{Y}$ and $\mathrm{Zr}$ shows distinctive volcanic arc signatures for all the three series, related to an active continental margin magmatism. It may have occurred before the opening of the Japan Sea. 
1. Tholeiitic Volcanism

Noto Peninsula

Volcanic Arc

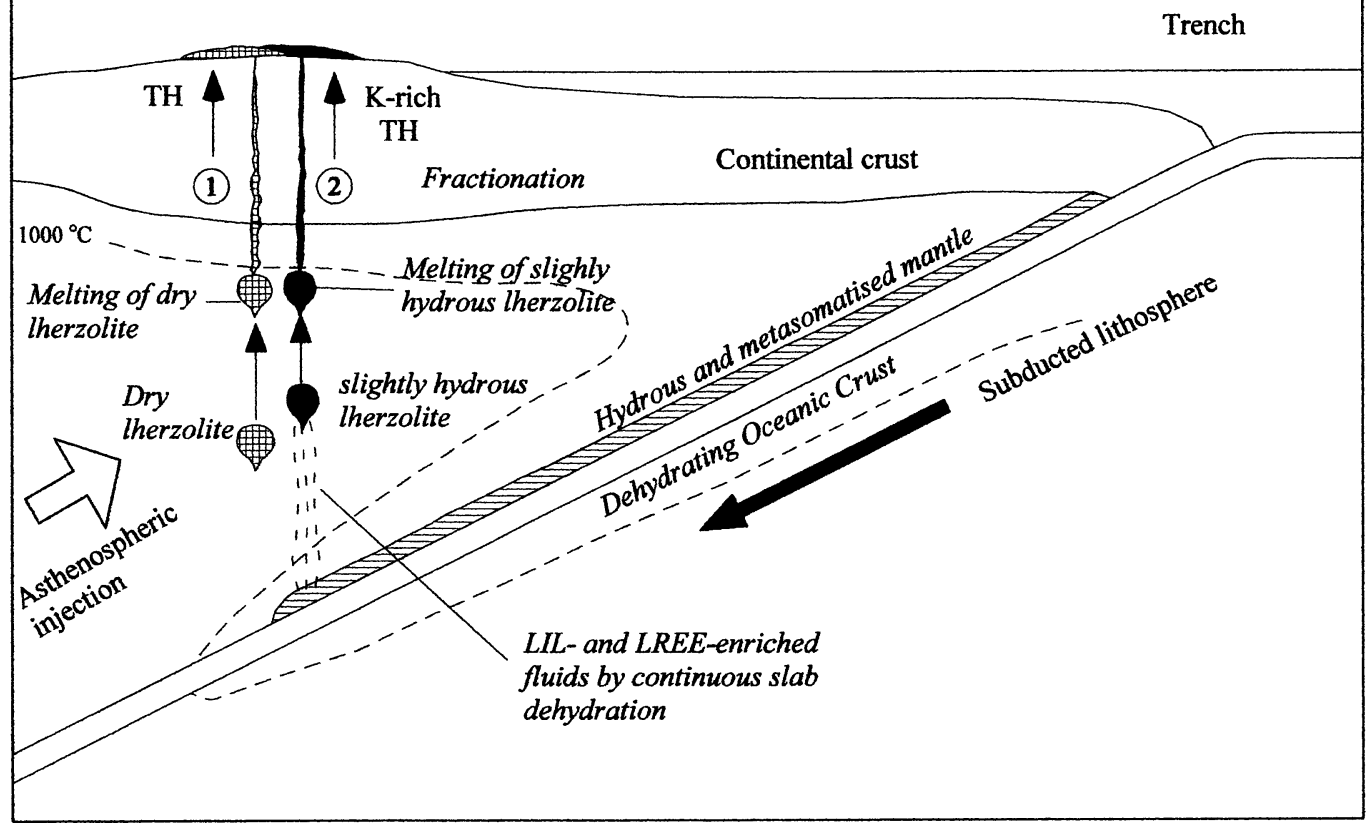

2. Calc-alkaline and HMA Volcanism

(b)

Noto Peninsula

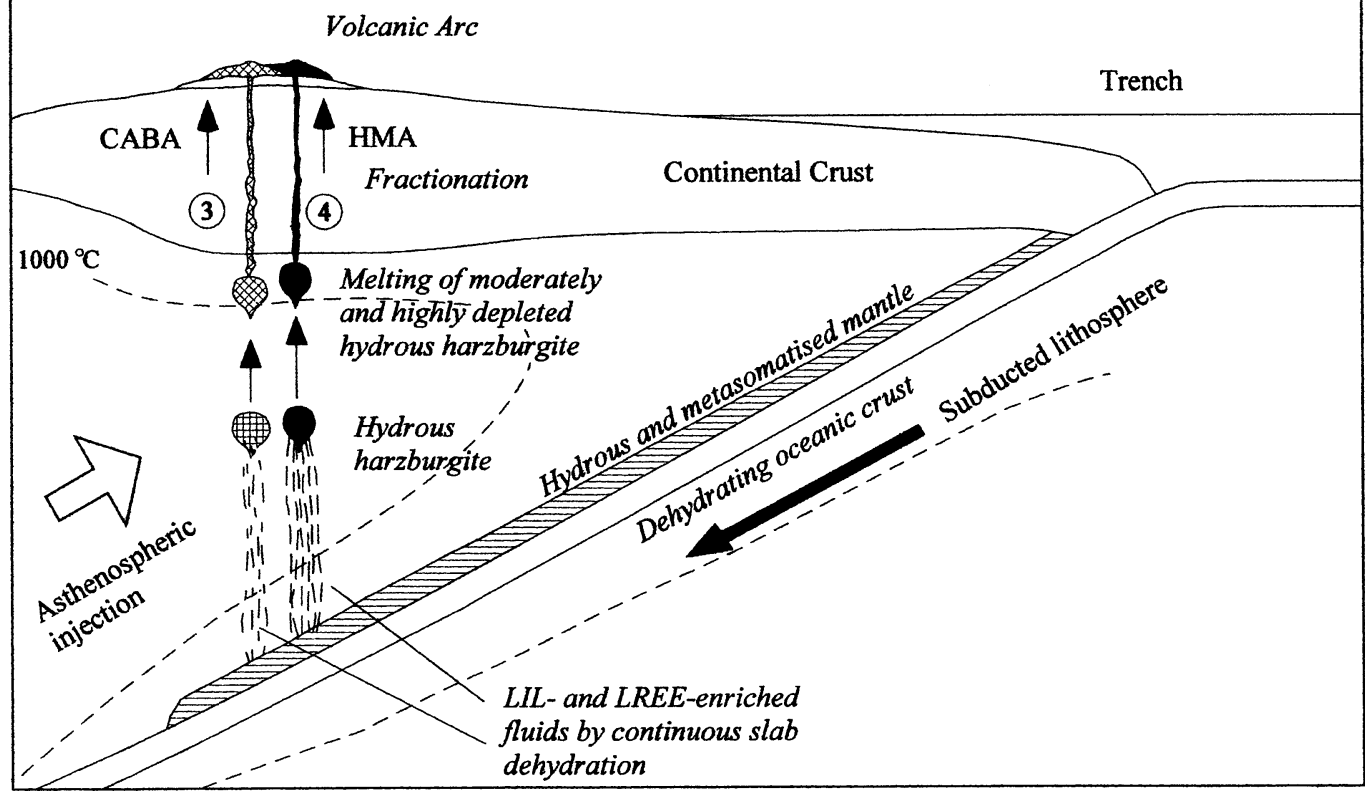

Figure 15. Models of successive generation of tholeiitic, calc-alkaline and high-magnesian andesite magmas within an active continental margin. a) Tholeiitic $\mathrm{K}$-poor and $\mathrm{K}$-rich magmas may have derived from anhydrous and hydrous (metasomatized) mantle sources respectively. b) Calc-alkaline and high-magnesian andesite magmas may be generated from a hydrous residual peridotite, metasomatized by fluids coming from the subducted slab (after Hickey and Frey, 1982; Tatsumi, 1991). 
3. Spinel compositions indicate progressive depletion or increasing degree of partial melting of the mantle source in the order tholeiite $\rightarrow$ calc-alkaline $\rightarrow$ bronzite andesite.

4. The $\mathrm{K}$-poor and $\mathrm{K}$-rich tholeiitc magmas have been produced by partial melting of lherzolitic sources in the upper mantle under anhydrous and slightly hydrous conditions, respectively. LILE-bearing hydrous fluid has affected the latter source. The calcalkaline and bronzite andesite magmas have been formed by partial melting of a depleted mantle source (harzburgite), which was contaminated with LILE- and LREE-enriched fluids that were supplied by dehydration of subducted lithosphere, under moderately and highly hydrous conditions, respectively.

\section{Acknowledgements}

Professor S. Arai and Dr. Y. Tamura are appreciated for constructive discussions and suggestions. The authors are grateful to Professor K. Shuto and Dr. N. Tsuchiya, for their helpful and constructive reviews of the manuscript. We thank Professor Y. Sasayama of the Noto Marine Laboratory of Kanazawa University at Ogi for his help in our fieldwork. Drs. T. Tsujimori, H. Shukuno, Messrs. M. Motoya, K. Kadoshima, and Miss N. Ueda are appreciated for their assistance in our field and laboratory works. Mrs. H. Hagiwara-Hoshino is thanked for providing her unpublished data for the Ishiyasumiba HMA.

\section{References}

Arai, S. (1987) An estimation of the least depleted spinel peridotite on the basis of olivine-spinel mantle array. Neues Jahrbuch für Mineralogie Monatshefte, 8, 347-354.

Arai, S. (1994) Compositional variation of olivine-chromian spinel in $\mathrm{Mg}$-rich magmas as a guide to their residual spinel peridotites. Journal of Volcanology and Geothermal Research, 59, 279-293.

Arai, S. and Muraoka, H. (1992) Peridotite xenoliths in alkali basalts from On-yama, the Chugoku district, as a suite of fertile upper mantle peridotites beneath the Southwest Japan arc. Journal of Mineralogy, Petrology and Economic Geology, 87, 240-254 (in Japanese with English abstract)

Arai, S., Hirai, H. and Uto, K. (2000) Mantle peridotite xenoliths from the southwest Japan arc: a model for the sub-arc upper mantle structure and composition of the western Pacific rim. Journal of Mineralogical and Petrological Sciences, 95, 9-23.

Basaltic Volcanism Study Project (1981) Basaltic volcanism on the terrestrial planets. Pergamon Press, New York

Crawford, A., Falloon, T. and Green, D. (1989) Classifica- tion, petrogenesis and tectonic setting of boninites. In Boninites and related rocks (Crawford, A. Ed.). Unwin Hyman Ltd., London, 1-49.

Defant, M. and Drummond, M. (1990) Derivation of some modern arc magmas by melting of young subducted lithosphere. Nature, 347, 662-665.

Dick, H.J.B. (1977) Partial melting in the Josephine peridotite I. The effect on mineral composition and its consequence for geobarometry and geothermometry. American Journal of Science, 277, 801-832.

Ebihara, M., Nakamura, Y., Wakita, H., Kurasawa, H. and Konda, T. (1984) Trace element composition of Tertiary volcanic rocks of northeast Japan. Geochemical Journal, 18, 287-295.

Foden, J. (1983) The petrology of the calc-alkaline lavas of Rindjani volcano, East Sunda arc: a model for island arc petrogenesis. Journal of Petrology, 24, 98-130.

Fujii, S., Kaseno, Y. and Nakagawa, T. (1992) Neogene paleogeogrphy in the Hokuriku region, central Japan, based on the revised stratigraphic correlation. The Memoirs of the Geological Society of Japan, 37, 85-95 (in Japanese with English abstract).

Fujinawa, A. (1988) Tholeiitic and calc-alkaline magma series at Adatara volcano, northeast Japan: 1. Geochemical constraints on their origin. Lithos, 22, 135-158.

Gill, J. (1981) Orogenic andesites and plate tectonics. pp. 390, Springer-Verlag. Berlin-Heilderberg.

Green, D., Edgar, A., Beasley, P., Kiss, E. and Ware, N. (1974) Upper mantle source for some hawaiites, mugearites and benmoreites. Contributions to Mineralogy and Petrology, 48, 33-43

Hickey, R. and Frey, F. (1982) Geochemical characteristics of boninite series volcanics: implications for their source. Geochimica et Cosmochimica Acta, 46, 2099-2115.

Hickey, R., Frey, F. and Gerlach, D. (1986) Multiple sources for basaltic arc rocks from the Southern Volcanic Zone of the Andes $\left(34^{\circ}-41^{\circ} \mathrm{S}\right)$ : trace element and isotopic evidence for contributions from subducted oceanic crust, mantle, and continental crust. Journal of Geophysical Research, 91, B6, 5963-5983.

Hirose, K. (1997) Melting experiments on lherzolite KLB-1 under hydrous conditions and generation of highmagnesian andesitic melts. Geology, 25, 1, 42-44.

Hoshina, H. (1984) Neogene volcanic rocks in the northern part of the Noto Peninsula, with special reference to aphyric andesites. The Memoirs of the Geological Society of Japan, 24, 45-58 (in Japanese with English abstract).

Ishida, S. (1959) The Cenozoic strata of Noto, Japan. Memoirs of the College of Science, University of Kyoto, B, $25,2,83-101$

Ishida, S. (1970) The Noroshi Flora of Noto Peninsula Central Japan. Memoirs of the Faculty of Science, Kyoto University, Series of Geology and Mineralogy, 37, 1, 1112.

Ishida, S. and Masuda K. (1956) Geology of the northeastern region of Noto Peninsula, Japan. Journal of the Geological Society of Japan, 62, 735, 703-716 (in Japanese with English abstract).

Ishiwatari, A. (1985) Granulite-facies metacumulates of the Yakuno ophiolite, Japan: Evidence for unusually thick oceanic crust. Journal of Petrology, 26, 1-30.

Ishiwatari, A. and Ohama, H. (1997) Clinopyroxene basalt 
dikes in the Miocene Iwaine Formation, Hokuriku Province, Japan: various continental arc magmas including shoshonite series and origin of the clinopyroxene phenocrysts. The Journal of the Geological Society of Japan, 103, 6, 565-578 (in Japanese with English abstract).

Johannes, W. (1978) Melting of plagioclase in the system $\mathrm{Ab}-\mathrm{An}-\mathrm{H}_{2} \mathrm{O}$ and $\mathrm{Qz}-\mathrm{Ab}-\mathrm{H}_{2} \mathrm{O}$ at $\mathrm{P}_{\mathrm{H}_{2} \mathrm{O}}=5$ kbars, an equilibrium problem. Contributions to Mineralogy and Petrology, 66, 295-303.

Kaseno, Y. (1993) Geology of Ishikawa-Ken, Japan (with Geological Maps, 1: 100000). Ishikawa Prefectural Government, pp. 321 (in Japanese).

Kushiro, I. (1974) Melting of hydrous upper mantle and possible generation of andesitic magma: an approach from synthetic systems. Earth and Planetary Science Letters, 22, 294-299.

Kushiro, I. (1990) Partial melting of mantle wedge and evolution of island arc crust. Journal of Geophysical Research, 95, B10, 15929-15939.

Masuda, A., Nakamura, N. and Tanaka, T. (1973) Fine structures of mutually normalized rare-earth patterns of chondrites. Geochimica et Cosmochimica Acta, 37, 239248.

Melson, W., Vallier, T., Wright, T., Byerly, G. and Nelen, J. (1976) Chemical diversity of abyssal volcanic glass erupted along Pacific, Atlantic and Indian Ocean sea-floor spreading centers. In The geophysics of the Pacific Ocean basin and its margin. American Geophysical Union, Washington D.C., 351-367.

Miyake, Y. (1994) Geochemistry of igneous rocks of Shimane Peninsula, formed within a Miocene back-arc rifting zone at the Japan Sea margin. Geochemical Journal, 28, 451472.

Miyashiro, A. (1974) Volcanic rock series in island arc and active continental margins. American Journal of Science, 274, 321-355.

Miyashiro, A. (1975) Volcanic rock series and tectonic setting. Annual Review of earth and Planetary Sciences, 3, 251-269.

Miyashiro, A. (1978) Nature of alkalic volcanic rocks series. Contributions to Mineralogy and Petrology, 66, 91-104.

Murton, J., Peate, D., Arculus, R., Pearce, J. and Van der Laan, S. (1992) Trace-element geochemistry of volcanic rocks from site 786: the Izu-Binin forearc. In Proceeding of the Ocean Drilling Program, Scientific Results, 125, 211-235.

Mysen, B. (1979) Trace element partitioning between garnet peridotite minerals and water-rich vapor: experimental data from 5 to 30 kbar. American Mineralogist, 64, 274287.

Nakada, S., Yanagi, T., Maeda, S., Fang, D. and Yamaguchi, M. (1985) X-ray fluorescence analysis of major elements in silicate rocks. Science Report of Kyushu University, 14, 3, 103-105 (in Japanese with English abstract).

Nohda, S. and Wasserburg, G. (1986) Trends of Sr and Nd isotopes through time near the Japan Sea in northeastern Japan. Earth and Planetary Science Letters, 78, 157-167.

Nohda, S., Tatsumi, Y., Otofuji, Y., Matsuda, T. and Ishizaka, K. (1988) Asthenospheric injection and back-arc opening: isotopic evidence from northeast Japan. Chemical Geology, 68, 317-327.

Ohki, J., Shuto, K. and Kagami, H. (1994) Middle Miocene bimodal volcanism by asthenospheric upwelling: $\mathrm{Sr}$ and
$\mathrm{Nd}$ isotopic evidence from the back-arc region of the northeast Japan arc. Geochemical Journal, 28, 473-487.

Okamura, S. and Yoshida, T. (1989) High-magnesian, plagioclase phyric andesite from Okushiri Island, Southwest Hokkaido. In High-Magnesian Andesites in Japan (Shiraki, K. Ed.). 167-176.

Pearce, J. (1982) Trace element characteristics of lavas from destructive plate boundaries. In Andesites: orogenic andesites and related rocks (Thorpe, R. Ed.). Wiley and Sons Ltd., Chichester, 525-548.

Pearce, J. (1983) Role of the sub-continental lithosphere in magma genesis at active continental margins. In Continental basalts and mantle xenoliths (Hawkesworth, C. and Norry, M. Eds.). Shiva, Nantwich, 230-249.

Sato, H. (1977) Nickel content of basaltic magmas: identification of primary magmas and a measure of the degree of olivine fractionation. Lithos, 10, 113-120.

Sato, H. (1989) Study on genetic environment of highmagnesian andesites. Report for JSPS grant, General Study C, 1988, pp. 99 (in Japanese).

Sato, H., Yamazaki, M., Kaseno, Y., Shimizu, S. and Itaya, T. (1989) Bronzite andesites from Hegura-jima and Nanatsu-jima Islands, Ishikawa-Ken. In High-Magnesian Andesites in Japan (Shiraki, K. Ed.). 163-166 (in Japanese).

Saunders, A., Rogers, G., Marriner, G., Terrell, D. and Verma, S. (1987) Geochemistry of Cenozoic volcanic rocks, Baja California, Mexico: implications for the petrogenesis of post-subduction magmas. Journal of Volcanology and Geothermal Research, 32, 223-245.

Shibata, K., Sato, H. and Nakagawa, M. (1981) K-Ar ages of volcanic rocks from the Noto Peninsula. Journal of Mineralogy, Petrology and Economic Geology, 76, 248252 (in Japanese with English abstract).

Shimazu, M., Kagami, H., Kawano, Y. and Yamamoto, G. (1993) Geochemistry of Early-Middle Miocene volcanic rocks in the backarc region of Japan: Sado, Noto and Tadami areas. Journal of the Geologiacl Society of Japan, 99, 10, 799-811.

Shukuno, H. and Arai, S. (1999) Olivine-chromian spinel compositional relationships of the Cenozoic alkali basalts from southwest Japan: implication for their mantle restites. Journal of Mineralogy, Petrology and Economic Geology, 94, 120-140.

Shuto, K. (1988) Miocene abyssal tholeiite-type basalts from Tobishima Island, eastern margin of the Japan Sea. Journal of Mineralogy, Petrology and Economic Geology, 83, 257-272 (in Japanese with English abstract).

Shuto, K., Izaki, T. and Yashima, R. (1985) Tertiary $\mathrm{TiO}_{2}-$ rich tholeiite from northern part of Motegi district of Tochigi Prefecture, northeast Japan. Journal of Mineralogy, Petrology and Economic Geology, 80, 246-262 (in Japanese with English abstract).

Shuto, K., Kagami, H., Yamamoto, M., Watanabe, N., Yamamoto, K., Anzai, N. and Itaya, T. (1993) The relationships between drastic changes in $\mathrm{Sr}$ isotope ratios of magma sources beneath the NE Japan arc and the spreading of the Japan Sea back-arc basin. Mineralogy and Petrology, 49, 71-90.

Sisson, T. and Grove, T. (1993a) Experimental investigations of the role of $\mathrm{H}_{2} \mathrm{O}$ in calc-alkaline differentiation and subduction zone magmatism. Contributions to Mineral- 
ogy and Petrology, 113, 143-166.

Sisson, T. and Grove, T. (1993b) Temperatures and $\mathrm{H}_{2} \mathrm{O}$ contents of low-MgO high-alumina basalts. Contributions to Mineralogy and Petrology, 113, 167-184.

Stern, C. and Kilian, R. (1996) Role of the subducted slab, mantle wedge and continental crust in the generation of adakites from the Andean Austral volcanic zone. Contributions to Mineralogy and Petrology, 123, 263-281.

Sun, S. and McDonough, W. (1989) Chemical and isotopic systematics of oceanic basalts: implications for mantle composition and processes. In: Magmatism in the Ocean Basins (Saunders, A. and Norry, M. Eds.). Geological Society of London, Special Publication, 42, 313-345.

Takahashi, T. and Shuto, K. (1999) Genesis of adakitic andesite, high-magnesian andesite, calc-alkaline andesite and tholeiitic andesite in the Miocene Iwaine Formation, southern part of Toyama Prefecture, Japan. Journal of the Geologiacl Society of Japan, 105, 11, 789-809 (in Japanese with English abstract).

Tamura, S., Kobayashi, Y. and Shuto, K. (1989) Quantitative analysis of the trace elements in silicate rocks by $\mathrm{X}$-ray fluorescence method. Earth Science (Chikyu Kagaku), 43, 3, 180-185 (in Japanese).

Tamura, Y. (1994) Genesis of island arc magmas by mantle -derived bimodal magmatism: evidence from the Shirahama Group, Japan. Journal of Petrology, 35, 3, 619 -645 .

Tamura, Y. and Nakamura, E. (1996) The arc lavas of the Shirahama Group, Japan: Sr and Nd isotopic data indicate mantle-derived bimodal magmatism. Journal of Petrology, 37, 6, 1307-1319.

Tanaka, K. and Nozawa, T. (1977) Geology and mineral resources of Japan. Geological Survey of Japan, Third Edition.

Tatsumi, Y. (1991) Origin of subduction zone magmas based on experimental petrology. In Physical chemistry of Magmas (Perchuk, L. and Kushiro, I. Eds.). SpringerVerlag, New York, 268-301.

Tatsumi, Y. and Ishizaka, K. (1981) Existence of andesitic primary magma: an example from southwest Japan. Earth and Planetary Science Letter, 53, 124-130.

Tatsumi, Y. and Ishizaka, K. (1982a) Magnesian andesite and basalt from Shodo-Shima Island, southwest Japan, and their bearing on the genesis of calc-alkaline andesites. Lithos, 15, 161-172.

Tatsumi, Y. and Ishizaka, K. (1982b) Origin of highmagnesian andesites in the Setouchi volcanic belt, southwest Japan, I. Petrographical and chemical characteristics. Earth and Planetary Science Letters, 60, 293-304.

Tatsumi, Y., Otofuji, Y., Matsuda, T. and Nohda, S. (1989) Opening of the Sea of Japan back-arc basin by asthenospheric injection. Tectonophysics, 166, 317-329.

Terakado, Y., Fujitani, T. and Walker, R. (1997) $\mathrm{Nd}$ and $\mathrm{Sr}$ isotopic constraints on the origin of igneous rocks resulting from the opening of the Japan sea, southwest Japan. Contributions to Mineralogy and Petrology, 129, 75-86.

Uematsu, M., Shuto, K. and Kagami, H. (1995) Genesis of tholeiitic basalt, high magnesian andesite, bronzite andesite and adakite-like andesite of the Late Oligocene Anamizu Formation, northern Noto Peninsula, Japan. Memoirs of the Geological Society of Japan, 44, 101-124 (in Japanese with English abstract).

Wendt, J., Regelous, M., Collerson, K. and Ewart, A. (1997) Evidence for a contribution from two mantle plumes to island-arc lavas from northern Tonga. Geology, 25, 7, 611-614.

Wood, D. (1978) Major and trace element variations in the Tertiary lavas of eastern Iceland and their significance with respect to the Iceland geochemical anomaly. Journal of Petrology, 19, 3, 393-436.

Woodhead, J., Eggins, S. and Johnson, R. (1998) Magma genesis in the New Britain Island arc: further insights into melting and mass transfer processes. Journal of Petrology, 39, 9, 1641-1668.

Yoder, H.S. Jr. (1969) Calc-alkaline andesites: experimental evidence bearing on the origin of their assumed characteristics. In Proceeding of the Andesite Conference (McBirney, A.R. Ed.). The Oregon Department of Geology and Mineral Industries Bulletin, 65, 77-89.

Manuscript received; 19 November, 2001

Manuscript accepted; 26 April, 2002 